Revista de la red interuniversitaria de estudios sobre las literaturas rioplatenses contemporáneas en Francia

\title{
El revés de la trama. Encuesta a once narradores
} contemporáneos

Sergio Bizzio, Leopoldo Brizuela, Sergio Chejfec, Oliverio Coelho, Sergio Delgado, Luisa Futoransky, Carlos Gamerro, Daniel Guebel, Martín Kohan, Damián Tabarovsky, Diego Vecchio

\section{Gersende Camenen y Mariana Di Ció}

\section{OpenEdition}

\section{Journals}

Edición electrónica

URL: http://journals.openedition.org/lirico/486

DOI: $10.4000 /$ lirico.486

ISSN: 2262-8339

Editor

Réseau interuniversitaire d'étude des littératures contemporaines du Río de la Plata

\section{Referencia electrónica}

Gersende Camenen y Mariana Di Ció, «El revés de la trama. Encuesta a once narradores

contemporáneos », Cuadernos LIRICO [En línea], 7 | 2012, Puesto en línea el 22 noviembre 2012

consultado el 19 abril 2019. URL : http://journals.openedition.org/lirico/486 ; DOI : 10.4000/lirico.486

Este documento fue generado automáticamente el 19 abril 2019.

\section{cc) (†) $\odot$}

Cuadernos LIRICO está distribuido bajo una Licencia Creative Commons Atribución-NoComercialSinDerivar 4.0 Internacional. 


\title{
El revés de la trama. Encuesta a once narradores contemporáneos
}

\author{
Sergio Bizzio, Leopoldo Brizuela, Sergio Chejfec, Oliverio Coelho, Sergio \\ Delgado, Luisa Futoransky, Carlos Gamerro, Daniel Guebel, Martín \\ Kohan, Damián Tabarovsky, Diego Vecchio
}

\section{Gersende Camenen y Mariana Di Ció}

1 Thomas Mann necesitaba una buena pluma y un papel de impecable blancura ("los obstáculos exteriores provocan otros, interiores") cuando Ungaretti y Apollinaire garabateaban en la urgencia de las trincheras y Hemingway gastaba las teclas de su Royal Arrow americana. La caligrafía de Borges tiene algo de esa "letra de insecto" que es la escritura de Pierre Ménard, Felisberto nos brinda una explicación falsa de sus cuentos ; Onetti, que apenas salía de su cama, nos dejó una escritura tumbada, y Kerouac escribió (o dice que escribió) On the road en veinte días, en un largo y único rollo de papel que él mismo confeccionó pegando innumerables hojas de caligrafía japonesas, hasta formar aquel mítico scroll de treinta y seis metros y medio de largo, cuyo final sería luego mordisqueado por un perro. Etcétera, etcétera.

2 Más allá de la anécdota en sí, de los gestos, ritos y manías que todos tenemos a la hora de sentarnos frente a la página o la pantalla en blanco, se trata pensar la relación entre las circunstancias materiales (lugar geográfico, eventualidades, contingencias, restricciones, instrumentos, soportes...) y la escritura misma. Si las prácticas o estrategias de escritura están en consonancia o en conflicto (¿por qué no ?) con el proyecto literario del que emanan. De pensar, en definitiva, la visión onírica y fragmentada de Xanadu como causa, y no como consecuencia, del sueño interrumpido de Coleridge, o de la visita inoportuna que pone fin a sus cavilaciones sobre Kubla Khan.

3 A la hora de pensar en una publicación de los Cuadernos LIRICO que pudiera dar cuenta de los distintos aspectos que intervienen en la escritura, nos pareció evidente que debíamos complementar las intervenciones críticas sobre los comienzos de un proyecto literario con la visión privilegiada de quien lucha a diario con el lenguaje. Con la idea de problematizar los modos y disparadores de la escritura, de cuestionar la idea de teleología en la escritura y la noción de linearidad en relación a la producción de un texto o corpus, 
propusimos a once narradores argentinos contemporáneos una serie de preguntas amplias en torno a las "arqueologías de escritura", con la consigna de que contestaran libremente. Aquí van las respuestas.

\section{Sergio Bizzio}

\section{1. ¿Podría contar, de la manera más detallada posible, cómo y dónde escribe?}

Escribo en dos mesas blancas. Una es rectangular, la otra es redonda. La mesa redonda está en la planta baja, en la cocina, y la mesa rectangular en la planta alta, en lo que podríamos llamar "estudio". Las dos mesas son fuertes y sólidas. La mesa de la cocina tiene una única pata de aluminio que se ensancha en la base (pop) y la mesa del estudio patas de madera clara, cruda. El estudio fue construido directamente sobre la cocina, de modo que las dos mesas están ubicadas en la misma vertical. Esa vertical es mi convento. La cocina da al jardín. El estudio a los techos de las casas vecinas. Ignoro por qué escribo a veces en una y a veces en otra. Las dos son igualmente cómodas. Las dos reciben el mismo aire y la misma luz. No sé nada sobre sillas, pero me dicen que el apellido de la silla de la cocina es "Jacobsen". La silla del estudio es una vieja MDF de cuero, giratoria, con apoyabrazos, que compré una década atrás. Son sillas felices, ya que paso mucho tiempo en ellas, pero no deciden nada. De modo que ni el aire, ni la luz, ni el punto de vista, ni el asiento. Tampoco la intimidad. (Hay una variación mínima en el grado de intimidad, según trabaje arriba o abajo). Escribo en una computadora portátil, así que, en caso de que mi mujer reciba amigos, o ante cualquier visita inoportuna, no hay nada más fácil para mí que mudarme al piso de arriba. Si las visitas tienen la confianza suficiente para pasar a la planta alta, pues entonces la mudanza es hacia abajo. Sé que en ese trámite, muy ocasional, resulto antipático. Fumo, y de tanto en tanto (en las pausas de la escritura) barro con una mano o con un dedo las esquirlas de ceniza que afean la superficie siempre limpia de la mesa. Limpia, no ordenada. Nunca lo está, nunca lo están. Siempre hay sobre ellas una buena cantidad de cosas que tienen y no tienen que ver con la tarea, desde libros y papeles hasta piedras recogidas en la playa y frasquitos de aceites que al ser quemados despiden fragancias de rosas o lavanda, en la mesa del estudio. La mesa de la cocina es un poco menos "culta" : frutas, llaves, bolsas de compras, boletas de impuestos. En este preciso momento escribo en la mesa del estudio y acabo de contar 37 cosas u objetos en total desorden alrededor de la computadora, incluyendo una comunicación fiscal, un pequeño mandril de vidrio y un bastidor de 30x30 en el que pinté hasta que me puse a escribir. Suelo pintar en los momentos de descanso. Es muy relajante (una ducha mental), sobre todo en largas jornadas de trabajo. Empiezo muy temprano, alrededor de las seis o siete de la mañana. Puedo escribir un par de horas o diez horas sin parar. Eso ya no depende de mí sino del texto, desde luego. He pasado días completos escribiendo. Semanas y meses de "días completos". A veces me intoxico, a veces almuerzo, a veces me derrumbo. De noche siempre tomo alcohol. Es el momento de revisar lo escrito durante el día. Cuando llega el alcohol, llega la corrección. Corregir es escribir en el interior del texto. Es el reino del desvío. Agrego, elimino, reescribo, me paseo por entre oraciones como en un bosque de especies nuevas, con una lupa en una mano y un machete en la otra. Es una tarea muy placentera para mí. 


\section{A la hora de escribir, ¿empieza por el principio ?}

Inevitablemente. Aunque en el resultado final, aquél principio haya desaparecido, o esté en otro lugar.

3. ¿Cómo se prepara para la escritura (lecturas, ritos, cábalas...) ?

No tengo ritos ni cábalas. Leo muy poca ficción durante la escritura de una novela.

4. ¿Cuándo considera que el texto está terminado?

Nunca es una "consideración". El final se siente (y se ve, también : es "lo que se ve venir"). Una curva melódica, a veces ligada al cansancio, raramente a la historia, y ante la que el oído, ya aguzado, etcétera.

\section{5. ¿Cuántas versiones escribe, en promedio, antes de publicar?}

Si "versión" se refiere a recomenzar de cero, la respuesta es : ninguna. O sólo una, la primera, con muchísimas correcciones, ajustes y cambios. Una constelación de miniversiones.

\section{6. ¿Conserva todo lo que escribe?}

No, al contrario, conservo muy poco de lo que escribo. No guardo intentos fallidos, ni párrafos sueltos, ni comienzos, ni esqueletos...

7. ¿Los relee alguna vez?

Una vez publicado, sí. Lo releo una vez, o dos, abriendo el libro en cualquier parte y desmayándome en todas.

8. ¿Tiene un archivo personal?

No. Trabajo siempre en un solo texto. En una sola novela, debería decir, ya que también escribo poemas y guiones de cine y a veces "salto" de un género a otro.

9. ¿Considera que uno puede decidir « entrar en literatura » o que es algo que simplemente acontece?

La inspiración tiene dos formas de presentarse : repentinamente (“ ¡Tengo una idea”!) o paso a paso ("¡Tengo una idea!"). La diferencia está en que en el primer caso hay que sostener y en el segundo encontrar.

10. ¿Cuándo se sintió escritor por primera vez ?

La primera vez que escribí una ficción tenía 12 años, pero no recuerdo haberme sentido escritor. Estaba maravillado.

11. ¿Le parece que se puede " aprender a escribir »?

Se puede aprender a escribir "bien", pero eso no significa nada: además de escribir bien, hay que ser bueno. Pasa lo mismo con las ideas. Se puede tener una idea genial, pero eso no alcanza : además hay que escribir.

\section{Leopoldo Brizuela}

4 Antes de comenzar a contestar las preguntas, permítanme decir me llena de felicidad poder hablar de estos temas que, desde hace mucho tiempo, considero los más propios y específicos de un escritor. Nunca un posible intercambio entre los escritores y los críticos e investigadores me parece más promisorio, que cuando se enfoca la génesis de los textos y todo cuanto la rodea. 
5 Celebro poder hablar de estas cosas en un tiempo en que la figura del escritor parece, al menos en Argentina, más que nunca menospreciada. ¿Cuál es la razón por la que el saber específico de un escritor interese, en apariencia, a tan pocos? Tengo mis hipótesis, por supuesto, no es este el lugar para desarrollarlas. Sólo quiero decir que la situación llega a un punto que, por ejemplo, en las entrevistas periodísticas, suele interrogarse al escritor como si fuera un crítico de su propia obra, o un estudiante universitario en tren de rendir el examen de Literatura Argentina Contemporánea II.

6 Y aquello de lo que muchos, como yo, querríamos hablar, queda siempre en silencio. Por supuesto, no hago este reclamo por una mera cuestión de disgusto personal. También a muchos se nos hace obvio que la inexistencia de testimonios sobre "el oficio" del narrador dificulta el surgimiento y la consolidación de una literatura.

7 En mi caso, paralelo a la búsqueda, digamos, puramente "literaria" que puede apreciarse en cada obra -búsqueda de una voz, de un estilo, de herramientas y destrezas técnicas, etc.- hubo un proceso menos visible pero no menos constante: la construcción de un espacio de escritura (tanto más ardua porque nadie esperaba que alguien como yo lo construyera), y la lenta búsqueda, básicamente por ensayo y error, de los hábitos más apropiados a mis necesidades.

8 Esa fue una de las principales razones por las que, también desde el comienzo, traté de acercarme a escritores mayores; sólo en el trato cotidiano podía enterarme de cómo hacían ellos, acceder a ese saber que nadie publica en la Argentina.

9 A esta altura de mi vida, empezar a escribir un libro, por distinto que sea de los anteriores, implica retomar esa serie de costumbres que, más allá incluso de mi conformidad con el texto, me da una enorme tranquilidad; el caos de la vida se olvida un poco gracias a ese pequeño cosmos creadle que surge la literatura.

1. ¿Podría contar, de la manera más detallada posible, cómo y dónde escribe ? ¿Sigue escribiendo a mano ? ¿Hay algún instrumento o soporte que privilegia ?

Me considero esencialmente un escritor de novelas y cuentos. No porque crea que lo haga bien o mal ; sólo siento que "el instante existe y mi vida está completa" cuando tengo en curso algún proyecto de escritura de ficción. Voy a referirme al proceso de escritura de estos relatos literarios, dejando sentado que escribir un ensayo o un artículo periodístico es una actividad cuya radical diferencia me complace incluso acentuar, para tener la sensación de que estoy de vacaciones y no, como sucede la mayoría de las veces, realizando un trabajo por encargo.

Desde mucho antes de empezar a escribir, incluso desde mucho antes de pensar que iba a ser un escritor todos mis relatos han vivido en mí de manera más o menos larvada. Han sido imágenes sueltas o frases que se me han aparecido y que, muchas veces sin que mediara un trabajo conciente mío, se han ido agenciando, un pasado y un futuro imaginarios, fundiéndose entre sí.

Escribo, entonces, muy rápidamente, una primera versión manuscrita, "a mano alzada", con infinidad de errores y lagunas: lo único que me importa en esta etapa es que aprovechar el impulso narrativo antes que se desgaste, y sobre todo, descubrir la estructura total del relato. Esa estructura que luego, durante meses, años incluso, rellenaré. Esta primera versión la escribo con pluma fuente y en cuadernos todos iguales. No se trata de mera obsesividad. Trabajar con cuadernos iguales permite tener una percepción concreta, física, de las proporciones del relato, de sus partes. 
El siguiente proceso es "pasar a computadora" (yo sigo hablando de "pasar a máquina") el texto -una práctica tan rica que es una de las razones por las que nunca dejé de manuscribir. "Pasar" es casi como volver a escribir el texto, con una distancia que permite percibir lo que el texto calla y sugiere. Después empieza el largo y, para mí, mucho más disfrutable proceso de corregir

Paralelamente, desde el mismo día en que empiezo a escribir y hasta el día que termino de corregir ya las pruebas de imprenta, voy llevando un cuaderno de notas. Durante la primera versión anoto en él, básicamente, las ideas que la propia escritura me sugiere y que más adelante utilizaré, y las correcciones y agregados que se me van ocurriendo para lo ya escrito.

Mientras paso la novela y la corrijo, anoto defectos que advierto, reflexiones sobre posibles maneras de corregirlos, y carencias que sólo puedo llenar por medio de la investigación ; por último, voy anotando también los resultados de esa investigación necesaria.

2. A la hora de escribir, ¿empieza por el principio ? ¿Cómo se prepara para la escritura (lecturas, ritos, cábalas...)?

Sí, escribo el libro en el mismo orden en que el lector va a recorrerlo, aunque casi nunca este orden coincida con el orden cronológico de la historia. Aunque tenga una idea previa de lo que va a suceder a lo largo del libro, es el capitulo anterior el que me sugiere el posterior; cada nuevo capítulo sale de la lectura pormenorizada, profunda, atenta, de lo que acabo de escribir.

Cuando era adolescente escribía muy tarde en la noche, cuando el resto de la familia se había ido a dormir. Ahora escribo muy temprano en la mañana, cuando todavía la familia no se levantó. No se trata simplemente de que, a esas horas, nadie interfiere con la creación. Sucede, quizás, que cuando escribimos dejamos de pertenecer al orden familiar, para pertenecer a una familia distinta, dispersa en el espacio, el tiempo y los diferentes lenguajes. Por lo demás, escribir tan temprano, permite, ya a las nueve de la mañana, tener la sensación de día cumplido; abocarse alegremente a otras tareas y pensar, en secreto, en lo que se va a escribir al día siguiente.

Escribo sentado en la cama, casi siempre, durante una o dos horas, en posición de escriba, sobre la misma mesita en que, en la infancia, se me traía la comida cuando estaba enfermo. Si estoy solo, escribo en la misma cama ; si estoy acompañado, para no despertar al compañero y nada rompa ese estado de sonambulismo que uno necesita provocarse, me traslado a un cuartito pequeño, dotado, a propósito de otra cama y almohadones. La perra, a mi lado, no molesta.

Hablo de sonambulismo, cuando quizá debería hablar de autohipnosis : en todo caso, no estoy buscando describir el momento de escritura por medio de metáforas, sino tratando de desentrañar un fenómeno psíquico muy concreto.

El momento de la escritura viene precedido por una serie de actos repetidos siempre de exacta manera ; son actos de tan poca importancia literaria -en mi caso : dar de comer a la perra, regar las plantas, preparar el mate, acomodarlo junto a la pava en una de las mesas de luz, etc.-, que parece descolocado llamarlos "ritos".

Pero su verdadera importancia está en nuestro modo de repetirlos, maquinalmente, casi sin intervención de la conciencia : es como si la mente se convenciera de que ya no 
hay razón para atender al mundo, y eso lo que permite ausentarnos cada vez más de la realidad, y "re-ligarnos" con ese orden surreal o sobrenatural que es la ficción en curso.

Pero existe un ritual que quizá pueda ser interesante detenerse antes de escribir, siempre necesité leer una o dos páginas de ciertos escritores; los leía sin leerlos realmente, sin saber que leía, sólo para que su tono, que llamo el de la "narración pura" porque me parece la trasposición literaria de la narración oral," me diera la entrada". Sí : como un director de coro que hace sonar el diapasón para dar el la a los que se aprestan a cantar, esos escritores me daban el tono en que yo empezaba a cantar mi propia historia. Son básicamente dos : Isak Dinesen y Charles Dickens.

Por último, más que de "cábalas", término que suena a arbitrario y antojadizo, preferiría hablar de cuidados. Por experiencia, me cuido cuanto puedo de hablar de lo que estoy escribiendo, y muchísimo más de que alguien pueda leerlos. Mi primer lector es mi agente, cuando la obra está casi terminada ; mi segundo lector es mi editor.

Decir que la creación literaria, tal como yo la entiendo, exige el secreto, sería demasiado. Pero es verdad que, al menos en mi caso, exige la mayor intimidad, esa en donde es posible el "diálogo del yo con el yo" del que hablaba Hanna Arendt. Por eso suelo sentir que la literatura es una actividad en extinción ; porque nada me parece más asediado que la intimidad de las personas.

3. ¿Cuándo considera que el texto está terminado? ¿Cuántas versiones escribe, en promedio, antes de publicar? ¿Conserva todo lo que escribe? ¿Qué hace con ellos? ¿Los relee alguna vez? ¿Tiene un archivo personal ?

Cuando me veo obligado a releer un texto mío, jamás siento que esté terminado. No se trata, creo, de perfeccionismo excesivo. Como a cualquier otro lector, el texto sigue haciéndome propuestas, no sólo de corrección y supresión, sino también de reescritura y de imaginación. La diferencia está en que yo me siento con derecho a que mis respuestas al texto se incorporen a él. Un error, sin duda. $Y$ acaso resistencia a perder al texto para siempre; a que, con sus defectos y errores, ya no me necesite.

Ahora bien, en cuanto al proceso de corrección, que, como dije, es mucho más largo que el de escritura, suele terminar por dos razones : 1) porque tengo una fecha inaplazable de entrega, o 2) por cierta forma de cansancio que quizás sea interesante analizar aquí. No se trata simplemente de agotamiento mental o físico, sino de una sensación de confusión absoluta, de haber olvidado los criterios por los que se ha corregido hasta el momento, e incluso cualquier otro código, de modo que se duda hasta de las verdades más elementales, como la corrección de que el sujeto anteceda al predicado o la existencia de la palabra "casa". Es el momento de abandonar el texto, porque cualquier decisión que se tome resultará, por supuesto, sumamente peligrosa.

¿Cuántas versiones escribo de cada relato ? Esta pregunta era más fácil de contestar en los tiempos en que escribía a máquina: cada vez que decidía volver a "pasar a máquina", era una versión, y tengo de esa época cuatro o cinco originales de cada relato. Pero ¿qué se considerará, en estos tiempos en que la computadora facilita tanto las correcciones, una versión? ¿Cuántas correcciones habilitan considerar que ya estamos trabajando en una versión nueva ? En cualquier caso, sería apropiado decir que hago innumerables versiones, y que sólo conservo, impresas, aquéllas que marcan hitos en la historia del relato: el manuscrito, la primera versión con mis correcciones manuscritas, el original que presenté al editor, etc. 
No, jamás releo mis relatos por voluntad propia. Siento una intolerable aprensión por mis propios libros, casi tan fuerte como el terror que siento cuando alguien los abre en mi presencia y se pone a leer, o cuando sé que alguien a quien desconozco me ha leído y ahora está cerca de mí. Creo que me da terror recordar que he quedado tan expuesto ante los lectores, a quienes ese saber sobre mí y mi propio terror revisten de una peligrosidad fastuosa.

Como quiera, es una pena, porque cuando, por obligación, repaso mis libros, contra todos esos temores, me hace muy bien : "No está tan mal como pensaba", me digo, pero eso no es lo más importante. Lo que me da mucha satisfacción es haber sido fiel a un proyecto narrativo que, simplemente, quería trasladar un mundo personal, con certezas e interrogantes a la página. Pensándolo así, hasta mi propio terror es un buen precio.

Pero eso sí, jamás releo, ni por casualidad, mis cuadernos de notas: siento que cumplieron su función ; aunque sin duda podría ayudarme al momento de esa respuesta imposible : “cómo se le ocurrió la novela ?" “cómo fue escribiéndola ?" Porque sucede que, igual que una ciudad oculta sus cimientos, todo relato terminado borra de la memoria los detalles de la gestación ; y uno, por buena educación, termina inventando para uso del entrevistador una historia más simple, completamente inadecuada.

Sí, tengo un archivo personal, en papel encarpetado, bastante ordenadamente. Tengo también el archivo de memoria de la computadora, donde figura todo lo que escribí en los últimos quince años, pero es obvio que, en el fondo, no siento que he escrito literatura hasta que no la veo impresa en papel.

4. ¿Considera que uno puede decidir « entrar en literatura » o que es algo que simplemente acontece? ¿Cuándo se sintió escritor por primera vez? ¿Cuál considera que es su primera obra?

No se puede por un mero acto de voluntad "entrar en literatura" -si esto es, verdaderamente, lo que intuyo-, pero tampoco se trata de algo que "simplemente acontece". La literatura es un acontecimiento que difícilmente se produciría si uno no lo propiciara en cada momento de vida : en cada observación de la realidad, en cada lectura, en cada decisión, etc. 0 mejor : si un deseo feroz, tan fuerte como lo más fuerte de uno, no nos llevara a propiciarlo como un asunto de vida o muerte. Somos porque escribimos; si no escribimos, sentimos que llega la muerte con tal lentitud que, más que morir, vivimos en muerte.

¿Cómo definir ese acontecimiento que llamamos literatura, desde el punto de vista de quien está escribiendo ? ¿Cómo distinguimos ese momento, tan similar en apariencia a otros momentos de escritura, si que el agente y la actividad son los mismos, y el producto casi idéntico para los demás? Cuando uno escribe literatura, cuando verdaderamente escribe, siente que es no es meramente un yo que expresa algo, uno es una antena por la que está pasando algo que viene de muy atrás y va hacia muy adelante.

En general, cuando se habla del "bloqueo" del escritor, se piensa únicamente en esos períodos en que no se escribe. No es mi caso. Por alguna razón, puedo llenar fácilmente páginas y páginas -como creo que puede hacerlo, a determinada altura, cualquier novelista profesional-. Todos podemos escribir una correcta novela mala, que, desgraciadamente, es lo que más abunda. 
Al mismo tiempo, puedo decir que tuve décadas enteras de bloqueo, porque ese acontecimiento llamado "literatura" no se producía; porque eso que escribía, aunque tuviera todas las apariencias de literatura, no lo era, era sólo superficie, y por eso terminaba aburriéndome. $Y$ no hay peor deshonestidad que escribir aburriéndose.

¿Por qué volví a ser parte del acontecimiento de la literatura? Sin duda, porque pasé por determinadas experiencias que me ayudaron a perder el terror que, también, nos provoca abandonarnos a escribir ; pero como esas experiencias bien pudieron no haber sucedido, y porque se conjugaron con otros factores igualmente fortuitos -que tuve tiempo, que tuve dinero, que alguien me había pasado cierto libro, etc.-- uno podría concluir que la "entrada en literatura" depende en gran parte del azar.

En general, a uno se le pregunta “¿cuándo empezó a escribir ?”. La pregunta “cuándo se sintió escritor por primera vez", me parece infinitamente más rica, aun cuando precisar una fecha de inicio, en temas así, siempre es un poco arbitrario. Empecé a escribir en enero 1976, a los doce años, cuando, intrigado por los hábitos de las mujeres de mi familia, leí un best seller que una tía había llevado a la playa. Era un best seller tan malo como para que sintiera que yo podía escribir algo parecido. .

Pero empecé a "sentirme escritor" un poco más adelante, durante el curso del mismo año, cuando empecé a atender a la biografía de los escritores, que aun hoy me parecen seres todos maravillosos.

A mis trece años, era "sentimiento", por supuesto, en gran parte infundado, pero tan poderoso que no ha variado en intensidad; sólo ha variado, digamos, en calidad, y no todo lo que debería. Sentirse escritor consiste en saberse parte de un gremio de gente ausente, dispersa por el mundo y las épocas, parte de una familia que, en gran medida, reemplazó a mi familia real. La pertenencia a esa familia era mi único privilegio, y me aferré a él con convicción, petulancia y locura de aristócrata. Ser escritor -una posibilidad no contemplada en el medio en que nací- era la posibilidad de escaparme del mundo, pero también de tomarme, más o menos intelectualmente, más o menos inteligentemente, una revancha.

¿Mi primera obra? Por alguna razón, todas pueden ser consideradas la primera: la primera que escribí -aquel melodrama de febrero del 76-, la primera que publiqué Tejiendo agua (1986), la primera por la que recibí un cierto reconocimiento Inglaterra (1999), etc. Pero tengo que decir que siento, como siempre, que la primera es la que estoy terminando en estos días. Y sin embargo, cuando la termine, sentiré que nunca he escrito nada, que la próxima será verdaderamente la primera.

5. ¿Le parece que se puede " aprender a escribir » ? ¿Qué diría en su caso ?

Por supuesto que se puede enseñar y aprender a escribir. Decir lo contrario sería una falta de respeto por mí mismo, ya que dediqué la vida a ambas cosas ; y una especie de burla a tanta gente que vi poner todo su esfuerzo en el estudio y la práctica de la literatura, y crecer gracias a ello como personas y como artistas.

Y sin embargo, entiendo que se dude de ello, porque, entre otras cosas, negarlo ha sido una de las herramientas usadas más frecuentemente por ciertos escritores para enmascarar su mezquindad: no han recibido nada de nadie, y por lo tanto, no reconocen la obligación, ni siquiera la posibilidad de darle algo a nadie. También, una manera de enaltecer la propia figura con un argumento muy semejante al "derecho divino" de las los monarcas absolutos : no han adquirido su habilidad, es un Don que, en 
definitiva, lo convierte en un Elegido entre el resto de los que reconocen una falta y pretenden aprender.

Pero es una verdad obvia como pocas que nadie ha escrito jamás una novela sin haber aprendido a leer una, a establecer los "pactos necesarios con el libro, y entender sus códigos ; sin haberse aplicado a investigar, en los libros, en las conversaciones con los maestros o, últimamente, en los talleres de escritura, cómo emplear en el discurso escrito, potenciándolas y diversificándolas, las capacidades narrativas innatas que usamos a diario en el discurso oral.

Es obvio que las elecciones de un escritor -tanto en lo puramente narrativo, literario, como en los diversos campos de su oficio- han sido elegidas por éste dentro de una gama que se preocupó por investigar, observando obras y autores. Facilitar tal investigación y tal hallazgo con la ayuda de su propia experiencia, es desde mi punto de vista, el trabajo del coordinador de un taller de escritura. Por supuesto, algunos tienen más facilidad que otros para aprender, para elegir y adoptar estas herramientas, eso que generalmente se llama "talento"; pero eso es todo.

Lo que no se puede ni aprender y enseñar es cómo provocar ese acontecimiento que llamamos literatura ; sencillamente porque, repito, tal cosa es imposible.

¿Qué podría agregar sobre mi caso? Marguerite Duras ha descrito cómo, cuando uno escribe verdaderamente, el mundo todo parece escribir con uno, colaborando con nuestra tarea : todo nos sirve, todo nos habla, todo nos alerta. Del mismo modo, creo que cuando uno no escribe está tratando de convencer al mundo -real y literario- de que nos diga su verdad, para que luego podamos trascribirla y replicarle, como se merece y en su misma altura, con nuestra escritura.

Más allá de la admiración que me despiertan, y de que no son los únicos que admiro, podría decir que algunos textos y escritores marcaron hitos en el proceso de aprendizaje. De Marta Lynch, una escritora que leyó mis primeros cuentos y me reveló hasta que la primera versión de un relato no era una fatalidad, sino una maravillosa incitación al trabajo. Aprendí y sigo aprendiendo de un artículo puramente preceptivo “Writing short stories", de Flannery O'Connor, así cómo de los cientos, miles de reglas para la construcción de un relato que Borges contrabandea en sus ficciones, sus ensayos y sus reportajes.

María Elena Walsh, desde mis catorce años hasta este mismo año, en que acaba de morir, me abrió no sólo el panorama de la narrativa de la que aún me siento heredero ; me enseñó que, aun al construir lo que suele llamarse una obra de "alta cultura", era muy posible ser fiel al folklore y la cultura popular, que yo -como ella- amaba desde la infancia. Durante veinte años, sin una sola frase que pudiera parecerse a una instrucción, Griselda Gambaro me enseñó a la importancia de construir un "cuarto propio", a no confundirlo con el ágora del comercio literario, y hacerlo respetar en todos los niveles.

6. ¿Cómo reacciona al escuchar hablar de «mala escritura »? ¿Le parece que hay un ideal de estilo ? ¿Qué opina de los ejercicios « de taller » 0 « de estilo »?

Cuando escucho hablar de "mala escritura" -o de "buena"- es lo mismo, me emociono. "¡De modo que no estoy solo!", me digo. Porque yo siempre he hablado en esos términos, y ya demasiadas veces me han hecho sentir que estaba equivocado o, para usar palabras más actuales, que hablar así "no es lo correcto". A mí me parece tan 
extraño como si me dijeran que el sol no es el sol: si me paso el día, por ejemplo, tratando de llevar un texto mío a su mayor nivel de potencia y posibilidad, es porque creo que existe lo malo, lo mejor, y lo bueno. ¿Por qué no podría decirlo de textos escritos por otros, si yo no les aplico mis propios criterios estéticos, si, por lo demás, digo que son malos cuando no llegan a lo que ellos mismos aspiran?

Quizá ésta no sea sino una de las variantes de la confusión que comentaba al principio : se confunden los criterios de cierta crítica con los criterios de un escritor. O para decirlo más claramente. Se confunde lo que es interesante, con lo bueno y con lo bello.

No objeto que libros como las memorias de la vida literaria de Manuel Gálvez se reediten en una editorial tan poderosa como Taurus, y con un prólogo de una crítica tan indiscutible como Beatriz Sarlo, porque evidentemente a Sarlo y a toda la universidad los fenómenos que describe Gálvez le sirven para estudiar. Pero ¿por qué no puede decirse, desde el punto de vista de un escritor, que Gálvez escribe una prosa horrorosa, que narra sin pericia alguna, etc. ?

En el otro extremo del espectro crítico, la actitud del amigo Damián Ríos que señala, entusiasta, "¡hay literatura en los fotologs !" y reenvía a sus lectores al sitio de Internet de una adolescente que narra lo que hizo en el día 1 sin puntos ni comas, me recuerda el trabajo del antropólogo o del recopilador, que atiende los fenómenos artísticos y los registra, sin hacer constar su gusto personal, el placer que les provocan. Disentir con Damián o mejor, decirle que ese fragmento es horrible, es tan incorrecto como decirle a un recopilador, "de acuerdo, así cantan los pigmeos, ipero que horrible ese pigmeo !"

$\mathrm{Y}$ es que creo que ese es el punto: el placer, la capacidad de un texto de provocar placer; y no sólo el placer intelectual, sino ese otro placer, tanto más complejo, que quizá podríamos llamar estético, y que involucra no sólo la capacidad de análisis, sino todas las zonas de la personalidad, incluso -y sobre todo-las que no manejamos y muchas veces no conocemos. Creo que hay un profundo miedo de abandonarse a ese placer que nos provocan las grandes novelas, porque exigen que suspendamos los criterios que sostenemos para analizarlas y por lo tanto, nos ponen en riesgo de profundo cambio. En cierto modo, la literatura que me parece más lograda es la que consigue ganarse el abandono del lector al placer absoluto. Y creo que si esto sucede es porque el escritor se abandonó primero al proceso de creación de la obra.

Por supuesto que no hay un solo ideal de estilo, pero, como decía más arriba, cada uno tiene el suyo, y no hay por qué negarlo. Es obvio además, que nadie tiene un ideal de estilo absolutamente particular, que aun el ideal del más extraño de los escritores es compartido por muchos; de manera que tampoco es cierto que haya infinitos ideales de estilo, o tantos como escritores haya. Me parece hipócrita negarlo. Me parece un serio problema, eso sí, la incapacidad de disfrutar de otro estilo que no sea el propio.

¿Por qué parece tan natural y respetable la ejercitación en la formación de un pintor o un músico, y se la menosprecia tanto en el aprendizaje de la escritura? Creo que los ejercicios de taller o de estilo son extremadamente útiles. Es verdad que casi nunca generan textos de calidad literaria, pero no es ése su objetivo, sino la adquisición, por la práctica, de una nueva habilidad técnica. Una de mis principales preocupación como coordinador de talleres de escritura ha sido inventar ejercicios para mis alumnos, que les permitan, aunque sea por obligación, zafarse de las leyes por las que ellos mismos han elegido regirse hasta entonces; y sobre todo, narrar con esa irresponsabilidad que 
sólo permiten la ausencia de lectores y críticos, y de esa sensación tantas veces sobrecogedora de estar escribiendo Literatura.

\section{Sergio Chejfec}

1. ¿Podría contar, de la manera más detallada posible, cómo y dónde escribe? ¿Sigue escribiendo a mano ? ¿Hay algún instrumento o soporte que privilegia?

En general escribo en mi casa, donde hay un cuarto que uso como escritorio. Pero no es raro que por algún motivo escriba en otro lado, por ejemplo algún café o, más habitualmente, en la biblioteca de una universidad cercana. Cambiar de sitio no me complica, y también creo que me adapto bastante cuando estoy fuera de donde vivo, de paso en otro lugar. Casi exclusivamente escribo en computadora, y cuando no la tengo lo hago a mano, en un cuaderno que va reflejando esa misma discontinuidad derivada de la preferencia por el procesador de palabras. En un principio escribía a mano. Después oscilaba entre lo manuscrito y la máquina de escribir (era una especie de relación estrecha y promiscua la que había entre la escritura a mano y la máquina de escribir). La máquina de escribir somete a uno a determinados protocolos y distancias. La computadora fue para mí como volver a la escritura a mano, sin mediación mecánica de ningún tipo.

2. A la hora de escribir, ¿empieza por el principio ? ¿Cómo se prepara para la escritura (lecturas, ritos, cábalas...) ?

No tengo cábalas. Y creo que tampoco ritos, aunque no estoy seguro. Empezar por el principio ya es todo un rito, y lo mismo sería si empezara por el final o por cualquier otro lado. En cualquier caso, comienzo por lo que considero el principio, que la mayor parte de las veces queda efectivamente como inicio. No me preparo mayormente para escribir ; para mí es esencial alcanzar una frecuentación constante, diaria, con lo que voy escribiendo. Cuando usaba la máquina de escribir, me gustaba usar hojas tamaño oficio con muy poco margen lateral y superior e inferior, a un espacio entre líneas, como para ver después la hoja completamente teñida por la letra. Las correcciones a mano las escribía en la parte de atrás. Con la computadora tengo una preferencia similar : uso el mínimo interlineado y trato siempre de que el texto sea una pantalla continua de palabras. La corrección, en parte, para mí, es instalar un poco de blanco y aire en esos bloques, espera uno, condesados de palabras.

3. ¿Cuándo considera que el texto está terminado? ¿Cuántas versiones escribe, en promedio, antes de publicar? ¿Conserva todo lo que escribe? ¿Qué hace con ellos? ¿Los relee alguna vez ? ¿Tiene un archivo personal ?

No tengo archivo. Lo único que conservo es, a veces, las distintas versiones electrónicas o páginas que corresponden a fragmentos especialmente corregidos. Mi problema, obviamente un problema que no es tal, nada problemático, es que los procesadores de palabras, incluso los diseñados para escritores, no contemplan las escrituras que avanzan por expansión. En general obedecen a una organización por capítulos, que siguen pautas de avance narrativo convencional. Lo único que a veces conservo es la corrección manuscrita de textos impresos, que después vuelco, esas correcciones, de nuevo a la pantalla. Por otra parte, voy reescribiendo las narraciones a medida que avanzo. Y los avances se producen no necesariamente desde el final, lo último escrito para llamarlo de alguna manera, sino muchas veces desde puntos intermedios. Supongo entonces que "avances" no es la palabra más adecuada, pero por lo menos es gráfica. 
4. ¿Considera que uno puede decidir « entrar en literatura » o que es algo que simplemente acontece? ¿Cuándo se sintió escritor por primera vez? ¿Cuál considera que es su primera obra?

Creo que no hay reglas. La literatura es una de esas cosas que carece de normas y requisitos de entrada y de salida. Mi experiencia fue la de entrar a la literatura antes de tener nada terminado o presentable. Me consideré escritor no tanto por un acto de la voluntad, sino cuando vi que se me devolvía una imagen propia de escritor. Fue algo más bien mágico. Me invitan a participar en una mesa redonda de "jóvenes escritores" ; yo era el único sin libro, ni inédito ni mucho menos publicado. Después advertí que había sido ese encuentro lo que hizo de mí un escritor. De otro modo podría no haberlo sido. Por otra parte, la literatura argentina, y la latinoamericana en general, es bastante plástica y porosa.

5. ¿Le parece que se puede « aprender a escribir »? ¿Qué diría en su caso ?

Obviamente se aprende, aunque no siempre uno es conciente de lo aprendido.

6. ¿Cómo reacciona al escuchar hablar de «mala escritura »? ¿Le parece que hay un ideal de estilo ? ¿Qué opina de los ejercicios « de taller » 0 « de estilo»?

Hay requisitos de coherencia, aun dentro de la incoherencia, que cada obra debe respetar porque son las premisas que cada texto se impone para sí mismo. Fuera de eso, mi idea de la literatura es algo completamente abierto, que se alimenta de lo no literario (de los discursos considerados no literarios) para ir renovándose y expandiendo su circuito de connotaciones. Sería más apropiado hablar de varias formas de literatura. Hay una literatura volcada a los formatos convencionales, con canales de circulación aceitados y completamente visible e invisible a la vez. Después hay formas más privadas o semiprivadas. Y aparte hay infinitos lazos de comunicación entre todas ellas. No tengo opinión homogénea sobre los talleres o carreras de escritura. Supongo que depende la persona.

\section{Oliverio Coelho}

1. ¿Podría contar, de la manera más detallada posible, cómo y dónde escribe? ¿Sigue escribiendo a mano ? ¿Hay algún instrumento o soporte que privilegia?

Escribo muy poco a mano, sólo cuando viajo. Privilegio la computadora como soporte para escribir ficción. Escribo en el altillo de mi casa, siempre sentado en un sillón reclinable con ruedas y a veces cruzado de piernas. Raramente puedo escribir fuera de mi casa, salvo notas circunstanciales en mis diarios de viaje.

2. A la hora de escribir, ¿empieza por el principio ? ¿Cómo se prepara para la escritura (lecturas, ritos, cábalas...)?

Sí, empiezo por el principio. Si bien luego no respeto una cronología y puedo escribir capítulos intermedios antes del segundo capítulo, siempre me ciño a un principio: el momento de presentar a mi personaje. El final también lo encuentro a último momento. A veces luego agrego o quito algún capítulo que me parece necesario para balancear la estructura del libro. 
3. ¿Cuándo considera que el texto está terminado? ¿Cuántas versiones escribe, en promedio, antes de publicar? ¿Conserva todo lo que escribe? ¿Qué hace con ellos ? ¿Los relee alguna vez ? ¿Tiene un archivo personal ?

Considero que el libro está terminado cuando me canso de él. Ese cansancio suele llegar después de varias revisiones y correcciones. Pero pocas veces me ocurre que ese momento de cansancio coincide con la inminencia de la publicación. En general me ocurre antes, bajo la forma de una renuncia. Como escribo en computadora, no podría hablar de versiones, sino de una larga versión que muta. Corrijo sobre lo ya corregido como si fuera la primera vez, de modo que no podría hablar de versiones, sino de una versión final a la que llego retirando capas y puliendo.

4. ¿Considera que uno puede decidir « entrar en literatura » o que es algo que simplemente acontece ? ¿Cuándo se sintió escritor por primera vez? ¿Cuál considera que es su primera obra?

Es algo que simplemente sucede, que para mí viene asociado al fin de la infancia. No recuerdo cuando me sentí escritor por primera vez. En mi adolescencia, cada vez que terminaba una novela impublicable, me creía escritor. Pero no sé si me sentía escritor... Supongo que el espesor de ese sentimiento debe ser gradual, ya que lo ideal sería que se presentara como un sentimiento correspondido -un lector-. Considero que mi primera obra es Tierra de vigilia, mi primera novela. Todos los inéditos anteriores -poemas, cuentos, novelas fallidas-, no fueron más que experimentos entusiastas.

5. ¿Le parece que se puede « aprender a escribir »? ¿Qué diría en su caso ?

Se puede aprender a escribir leyendo, es decir, aprender a escribir sin saberlo. En el aprendizaje hay un gran trabajo de ese inconciente que se cultiva en la lectura y en el ocio. En mi caso la lectura y la escritura convivieron. Leí y escribí alocadamente. Ese fue mi aprendizaje.

6. ¿Cómo reacciona al escuchar hablar de «mala escritura »? ¿Le parece que hay un ideal de estilo ? ¿Qué opina de los ejercicios « de taller » o « de estilo»?

Creo que el término mala escritura muchas veces refiere, simplemente, una escritura que escapa a las convenciones. El ideal de estilo, a mi modo de ver, reside en respetar la propia singularidad y afinar una precisión subjetiva, no una precisión sanitaria.

\section{Sergio Delgado}

1. ¿Podría contar, de la manera más detallada posible, cómo y dónde escribe? ¿Sigue escribiendo a mano ? ¿Hay algún instrumento o soporte que privilegia?

Escribo directamente en la computadora. Si bien comencé, como todo el mundo, garabateando papeles y cuadernos, tecleando en una "máquina de escribir", mi verdadero ingreso en la escritura se produce con el aprendizaje, siempre incompleto y desesperante, del "sistema operativo" de una computadora y de un "procesador de texto". Hoy es tan habitual el uso de una computadora y el manejo de programas como Windows o Word que da la impresión de que esos instrumentos forman parte de una segunda naturaleza de las cosas, como el zapato que uno calza por las mañanas, a veces sin salir todavía de la cama. Ese zapato se olvida durante el día y sólo se vuelve evidente cuando nos aprieta. Mi menuda historia de escritor va en paralelo con esta historia instrumental. Recuerdo, de manera si se quiere física, las muchas vicisitudes vividas con el hoy primitivo DOS o con procesadores como WordStart, FrameWork o WordPerfect, como podría recordar una extracción de muela o una operación de apendicitis (nunca me 
operaron de apendicitis pero gracias a IBM creo tener una idea de lo que debe ser esa experiencia).

Nunca pude escribir "a mano". Siempre necesité de una mediación mecánica (a veces olvidamos que una PC es una máquina) entre los dedos y el papel. En mi juventud, entre los 14 y los 16 años, cuando comencé a tentar la posibilidad de ser escritor armé varios proyectos de "libros" (de relatos, de poemas, una o dos novelas), todos con máquinas de escribir (la tipografía, claro, como fetiche). Al principio con una vieja Remington familiar, luego con una Hermes portátil que me regalaron para un cumpleaños, con su lindo estuche que llevaba a todos lados como hoy alguien lleva su "Notebook"; alguna vez con una Brother eléctrica. Como hice un bachillerato general (distinto era el caso de los que por ejemplo hacían "comercial") en el colegio no me enseñaron mecanografía. Entonces fui a una academia privada para aprender a escribir a máquina. Necesitaba una "dactilografía", lo que se llama una escritura táctil, sin mirar las teclas, porque entendí, de alguna manera, que esa destreza me sería indispensable. Tengo el recuerdo material de la impresión en el papel de mis primeras frases, que iban acompañadas inmediatamente de una decepción, casi un dolor, ante los avatares de rodillos, tintas, errores de tecleo. Había ahí, en esos intentos, algo que comenzaba, pero eso todavía no era escritura.

A fines de los años 80 mi papá, contador, compró su primera computadora personal. Recién comenzaban a salir y eran muy caras. Todavía no existía el disco rígido y esas pesadas máquinas tenían una doble disquetera : en una iba el programa (WordStart fue el primero que utilicé) y en la otra se guardaban los datos. Eran unos disquetes enormes, del tamaño de un plato, que se llamaban "flexibles" y que eran muy frágiles. Enseguida me fascinó esa fragilidad porque era la garantía, un tanto paradójica, de una escritura que podía ser corregida y rescrita infinitamente.

En esa computadora comencé a escribir mi primer libro, La selva de Marte. La máquina no estaba destinada para ese trabajo, indudablemente, y esta desviación tenía su lado clandestino. Además al principio y durante un cierto tiempo había un desdoblamiento del espacio de trabajo. Por un lado estaba el lugar donde yo vivía y escribía y por el otro el lugar donde se encontraba la computadora. Esto implicó una estrategia de escritura en dos etapas, que en cierto modo todavía conservo, aunque se ha ido modificando: sobre la computadora y sobre lo impreso en papel. La impresión en el papel era un momento solemne, un momento casi de pasaje a un estado de concreción que, si bien provisorio, permitía una noción "material" de lo escrito. Luego el papel se llenaba de correcciones y agregados, se recortaba y se volvía a pegar, se agregaban otros papeles sueltos, y luego, finalmente, había que volver a la computadora a pasar todo "en limpio". La escritura avanzaba a fuerza de esa rutina en dos tiempos. En lo esencial tengo la sensación de que hoy sigo escribiendo de la misma manera, e incluso creo que perdura, en algún lugar de mi maltratado súper-yo, el misma sentimiento de estar desviando permanentemente el cometido de una máquina pensada, en realidad, para operaciones más lucrativas. Cuando pasado un cierto tiempo pude tener mi propia computadora, se anuló la distancia que separaba los dos espacios primitivos de trabajo, pero el ritmo en dos tiempos permanece. Lo mismo cuando, mucho después, tuve mi primera computadora portátil.

Trabajo en el lugar donde vivo, es decir : soy un escritor casero. No puedo trabajar en bares. No puedo escribir viajando. Si bien últimamente comencé a tener cuadernos o libretas, no los uso para escribir sino para anotar datos. Lo que escribo en esas circunstancias nunca son frases de escritura. Son más bien imágenes. Incluso en su 
sentido puramente visual : hace un tiempo comencé a pegar fotos en los cuadernos. Si eso es luego retomado por la escritura (gran parte de esas anotaciones forman parte de un proyecto en marcha que se llama por el momento Manzanas), todo eso es sometido, por parte de la escritura, a un trabajo como de traducción.

A pesar de que muchas cosas cambiaron, en las máquinas y en el espacio, siempre reencuentro el mismo misterio ante una hoja impresa. Hayan transcurrido, entre el teclado y el papel, segundos, minutos, horas, días e incluso años, siempre llego a esa letra como desde un país lejano.

2. A la hora de escribir, ¿empieza por el principio ? ¿Cómo se prepara para la escritura (lecturas, ritos, cábalas...)?

Nunca empiezo necesariamente por el principio. Trato de empezar por lo más difícil, lo que se resiste y me procura, en esa resistencia, una cierta necesidad de trabajo. Es el momento en que una frase logra una intensidad, un cierto ritmo, que me lleva a una segunda y luego a una tercera... La clave del trabajo está en la frase y su ritmo.

En realidad creo que el problema, al menos para mí, es que nunca tengo un principio de nada. Siempre tengo varios proyectos en marcha, en distinto grado de avance. Cuando termino de escribir un libro, lo último que escribo es por lo general el principio. $\mathrm{Y}$ a veces es lo único que vuelvo a revisar en la última prueba de corrección. El caso más patético, creo, es el de la novela El corazón de la manzana, publicada en 2008, que comenzó siendo un pequeño poema escrito en 1997 con la evocación de un sueño. Ese sueño quedó al comienzo y al final de la novela.

Este es mi modo de escribir, lo digo sin orgullo pero también sin prejuicio, y en torno del mismo se organiza mi ritual de la escritura. Siempre hay un rondar antes que un principiar. Y me resigno al despliegue de este marco amplio de trabajo que, lo sé, ¡cómo lo sé !, es enfermizo y angustiante (la angustia de estar como suspendido en el vacío, sin concretar nunca nada). Aunque siempre intento cambiar, termino resignándome. Pero esto tiene también su felicidad. Tratándose de novelas o de una colección de relatos, me gusta pasar el tiempo imaginándolas, construyendo un "mundo". Y acumulo fichas, textos sueltos, notas. Muchas cosas reposan y con otras avanzo en distintas direcciones, hasta un momento, que es en todo lo caso lo que más se parece a un principio, en el que un proyecto me atrapa. Me atrapa o se deja atrapar y entonces me concentro en eso exclusivamente.

Si bien es esencial ese momento en el que un proyecto capta todo mi tiempo y toda mi atención, hasta lograr una primera versión de algo que me deja medianamente conforme, me parece que lo esencial es lo otro, ese tiempo perdido, desperdiciado, de la espera, de la preparación, incluso de la inutilidad, en el que uno da vueltas sin saber dónde ir. Es curioso descubrir de qué modo la espera se convierte en la clave del escribir. La confianza, si se quiere ciega, de que algo resultará de tanto tiempo malgastado viene quizás con la experiencia pero nunca deja de tener su parte de enigma e incluso de delirio... ¿Si hiciera, acaso, algo más útil con mi vida? Y lo más curioso todavía es que, una vez que se logra una cierta confirmación, si acaso una vez las cosas salieron medianamente bien y valió la pena ese tiempo, en el proyecto siguiente nada de todo eso sirve de mucho. Se vuelve siempre a empezar desde cero. $Y$ me parece que está bien que el olvido, como las aguas del Leteo para el que vuelve del infierno, sea la condición fundamental de la escritura. 
3. ¿Cuándo considera que el texto está terminado? ¿Cuántas versiones escribe, en promedio, antes de publicar? ¿Conserva todo lo que escribe? ¿Qué hace con ellos ? ¿Los relee alguna vez ? ¿Tiene un archivo personal ?

Nunca logro escribir una frase directamente, de "un seul jet" como se dice. Tengo incorporada a mi manera de ser en la escritura, como una suerte de resignación, la idea de que una frase es algo que viene al cabo de un tiempo, no de escritura propiamente dicha, sino más bien de reescritura. La escritura, para mí, es como una suerte de palimpsesto invertido, donde la frase original es la última y aparece al cabo de todos los ensayos, al final de todos los borradores. Técnicamente puede decirse que de cada una de mis novelas tengo una serie de entre cinco y siete versiones, pero esta cifra no quiere decir nada porque en el interior de cada una de las frases de esas versiones se depositan las capas invisibles de muchos sedimentos.

Conservo esas cinco o siete versiones pero sólo como medida de seguridad. Por si se me borra un archivo. En ese caso puedo al menos recuperar una parte del trabajo perdido, como me ha sucedido muchas veces. Es curioso pero, en ese momento, es decir cuando por un error de manipulación se me borró el archivo en el que estaba trabajando y recupero un archivo inmediatamente anterior, puedo rápidamente rehacer el camino para volver a la situación última, como si hubiera conservado, en algún lugar de mi memoria (porque no está indudablemente en la computadora esa información) el trazo del borroneo. No sé qué sentido tiene esta capacidad porque se activa únicamente ante un fracaso, como una suerte de consolación. Consolación siempre insuficiente porque lo que se recupera nunca es lo mismo que se perdió.

Conservo en el disco rígido las diferentes versiones porque es fácil hacerlo y ocupa poco espacio. Pero no le veo ninguna utilidad a ese material una vez que el libro está impreso. De hecho nunca vuelvo a releerlo. Vuelvo más bien a revolver la basura, esa suerte de resto que queda de cada trabajo, como en una suerte de gran desván, con capítulos descartados o frases inconclusas dejadas de lado. En este sentido, un trabajo nunca está terminado. Sólo existe ese momento en el que se tiene que abandonarlo. Y me estimula pensar que algo valioso queda en los pedazos de madera o la viruta que se acumula en el piso, bajo la mesa de trabajo, que uno barre, recoge, pero no tira.

4. ¿Considera que uno puede decidir « entrar en literatura » o que es algo que simplemente acontece? ¿Cuándo se sintió escritor por primera vez? ¿Cuál considera que es su primera obra?

No sé si hay una decisión. Y tampoco estoy convencido de que sea importante que la hubiera. Lo que puedo decir, hablando a título personal, porque tengo al respecto un conocimiento privado, que debería ser diferente al de otra persona, es que escribir es algo absolutamente innecesario. Nada ni nadie, ninguna cosa de este mundo, ninguna persona ni institución, solicita eso que yo estoy escribiendo. Es más : todo parece conspirar, minuciosamente, contra ese tiempo frágil y provisorio que uno trata de reservar al trabajo de escritura.

Digo esto y soy consciente de que hablo desde un lugar de privilegio. No vivo de lo que escribo y nunca me hice ilusiones al respecto, pero ejerzo profesiones que no me alejan demasiado de la literatura, como la enseñanza, la edición de libros o la crítica. Incluso en esta situación de privilegio en la que me encuentro -y si alguna vez tuve alguna ilusión de que fuera distinto ya la he perdido-, las dificultades o los peligros no son muy diferentes de los que debería confrontar un escritor que trabaja por ejemplo en un banco. Nadie colabora, ni las personas ni las instituciones, para hacernos sentir, en algún momento, una determinada seguridad. No me siento escritor y nunca se me 
ocurriría completar con la palabra "Escritor" la casilla del formulario de migraciones donde, cada vez que ingreso en un país, se me pide una profesión; no por pudor sino porque descubro que esta suerte de indeterminación civil del ser escritor es, al menos para mí, esencial.

Y me parece que todo esto forma parte de un sentimiento respecto a la escritura, como que el ser escritor es un estado que nunca se termina de completar. Y está muy bien, me digo en los momentos de mayor optimismo, eso de escribir despojado de toda ilusión, confrontando el vacío con cada frase. Nunca es tan así, por otra parte. Pero es cierto también que se trata de una desilusión que no evoluciona con el tiempo.

Por otra parte, lo único verdadero es que hay un momento en que asumimos una suerte de destino de trabajo. En ese destino encuentro un "estado civil" pero no podría definirlo. Es un estado dentro del estado de las cosas. Una situación privada : está en relación con los proyectos personales. La necesidad de concluir un proyecto para salirnos de una vez por todas de él, que nos ha tenido atrapados durante meses o años, pero también, y sobre todo, para poder emprender el proyecto siguiente, que nos está esperando.

5. ¿Le parece que se puede " aprender a escribir »? ¿Qué diría en su caso ?

Si de lo que acabo de decir anteriormente se puede desprender alguna conclusión, al menos parcial, sería más o menos la siguiente : el arte de la escritura, como todo arte, exige un aprendizaje. Nadie nace escribiendo, esto es evidente. Esto es "lo" evidente. Todo lo otro, me parece, es que esa experiencia no se puede transmitir sino de manera parcial. La parte transmisible del arte de escribir es mínima, si acaso alguien logra definir una serie de reglas o estrategias. Lo fundamental, es decir el resto, es esa parte de tanteo, irresponsabilidad, equívoco, fracaso, desesperación, y sobre todo soledad, que nadie puede recomendar a ningún amigo. Si se transmite será como sucede con una enfermedad. Un enfermedad, hay que decirlo, poco contagiosa. Se escribe mucho pero hay poca literatura.

6. ¿Cómo reacciona al escuchar hablar de «mala escritura »? ¿Le parece que hay un ideal de estilo ? ¿Qué opina de los ejercicios « de taller » 0 « de estilo »?

Me deja indiferente. Creo que es un falso problema. Un verdadero planteo, me parece, no pasa por si hay una noción de buena o mala escritura, un prejuicio respecto al estilo, a lo que se piensa debe ser una "literatura de calidad" (¿una literaturidad?) porque en definitiva no es algo que el escritor pueda saber ni mucho menos decidir, sino si "hay o no hay escritura" : esa situación, más bien rara, ni siquiera ideal, donde escritor y lector se reconocen y se reconcilian. Quiero decir : el escritor que quizás hay en mí, en cada uno de nosotros, el lector que nunca dejamos de ser. Y lo que yo debo intentar ser, como escritor y también como lector, lo debo intentar con lo mejor de mí, la parte más generosa de mi persona, a través de la entrega más completa. Por qué voy a descartar o privilegiar, antes de comenzar a escribir, determinado tipo de materiales. No podría hacerlo porque todo, desde la lista de compras de un supermercado hasta una elaborada metáfora, puede ser objeto de literatura. Cómo voy a decidir antes de comenzar a escribir si voy a hacerlo "bien" o "mal", tratándose de algo respecto a lo cual no puedo tener un conocimiento definitivo ; mucho menos previo.

Otra cosa son los manifiestos, las consignas e incluso las provocaciones. Tienen su sentido, en determinados contextos, en este mundo despiadado, ridículo y esencialmente injusto en el que vivimos, pero ninguna obra literaria se hace con manifiestos, consignas, provocaciones. Cuando Macedonio Fernández habla de una 
"novela mala" o cuando César Aira habla de una novela sin terminar o abandonada con precipitación, esas declaraciones no definen, de ninguna manera, la calidad de sus escrituras. Pueden ayudar al escritor a ocupar un lugar en el mundo, pero no le ayudan a escribir. En esto me gustaría equivocarme. Todo sería más fácil si lo que acabo de decir no fuera cierto. El escribir, el hacer literatura, el hacer arte, exigen lo mejor de nosotros y a cambio nos devuelven poco o nada.

\section{Luisa Futoransky}

1. ¿Podría contar, de la manera más detallada posible, cómo y dónde escribe ? ¿Sigue escribiendo a mano ? ¿Hay algún instrumento o soporte que privilegia?

Escribo apenas me levanto, soy muy mañanera. A mano, en un cuaderno, sólo escribo cuando no estoy en casa, y las más de las veces el resultado es un galimatías que me es arduo cuando no imposible de descifrar. Desde hace unos veinte años privilegio las computadoras mac, en estos momentos poseo un portátil heredado que exige renovación.

2. A la hora de escribir, ¿empieza por el principio ? ¿Cómo se prepara para la escritura (lecturas, ritos, cábalas...)?

Después del primer café cada día me resulta un principio de página, aunque se trate de una novela.

3. ¿Cuándo considera que el texto está terminado? ¿Cuántas versiones escribe, en promedio, antes de publicar? ¿Conserva todo lo que escribe? ¿Qué hace con ellos? ¿Los relee alguna vez ? ¿Tiene un archivo personal ?

Nunca. Incluso luego de publicados a veces retomo textos, procedimiento que es más fácil con los poemas. Tiro y "pierdo" bastante. Tengo demasiado desorden y siempre viví en lugares exiguos como para tener archivos, aunque fantasmeo con ello y también con un secretario/a que se haga cargo de todos los trámites y asuntos enojosos, como tratar eficazmente con editores, por ejemplo.

4. ¿Considera que uno puede decidir « entrar en literatura » o que es algo que simplemente acontece? ¿Cuándo se sintió escritor por primera vez ? ¿Cuál considera que es su primera obra?

No sé si se puede "decidir" entrar en literatura pero no creo tampoco que "acontezca". Me sentí "escritora" y lo recuerdo nítidamente como un hito a los catorce. Mi primera obra es un libro de poemas, Trago fuerte, editado en Bolivia en 1963. Algo de lo que me enorgullezco es que nunca publiqué al menos hasta ahora, toco madera, a cuenta de autor.

\section{5. ¿Le parece que se puede " aprender a escribir »? ¿Qué diría en su caso ?}

Es un tema largo, con muchas puntas. Para mí lo principal es la práctica renovada, constante. Atentos a la música exigida por el propio discurso. Bucear hasta que palabra e intención se fundan en el mismo torrente.

6. ¿Cómo reacciona al escuchar hablar de «mala escritura »? ¿Le parece que hay un ideal de estilo? ¿Qué opina de los ejercicios « de taller » 0 « de estilo»?

Mala escritura es la que se encuentra dentro del libro que se te cae de las manos y ni con buenas intenciones podés volver a leer. En cuanto a los talleres me parecen positivos, los italianos dicen "tutto fa brodo", todo sirve. Dependerá de qué hacemos 
con todo cuanto sabemos y olvidamos y creemos que sabemos. Pero eso será tema de otra encuesta y harina de otro costal.

\section{Carlos Gamerro}

1. ¿Podría contar, de la manera más detallada posible, cómo y dónde escribe ? ¿Sigue escribiendo a mano ? ¿Hay algún instrumento o soporte que privilegia?

Escribo habitualmente en mi estudio, en un edificio separado de mi vivienda. Todo lo que sea ficción, lo escribo en primera versión a mano, en hojas tamaño oficio, de un solo lado, en tinta negra. Guiones, adaptaciones teatrales, ensayo, directamente en el ordenador.

2. A la hora de escribir, ¿empieza por el principio? ¿Cómo se prepara para la escritura (lecturas, ritos, cábalas...) ?

Prefiero escribir de mañana, pero no siempre puedo. Nunca de noche, ahora, salvo anotar un idea o fragmento que acudan espontáneos a mi mente. Si es de mañana, tomo mate. Si estoy haciendo ejercicios de estilo sobre otros autores, antes de empezar a escribir, leo, o escucho en el ipod, a mis modelos. Cuando hago yoga, me reservo las horas inmediatamente posteriores para escribir. Pero en última instancia, lo que importa a la hora de escribir no es el estado del escritor, sino el del material. Si éste está en caliente, detendré el auto para escribir, escribiré en salas de espera y aeropuertos, me levantaré de la cama en medio de la noche para hacerlo.

3. ¿Cuándo considera que el texto está terminado? ¿Cuántas versiones escribe, en promedio, antes de publicar? ¿Conserva todo lo que escribe? ¿Qué hace con ellos? ¿Los relee alguna vez ? ¿Tiene un archivo personal?

El texto está terminado cuando, como propone Raymond Carver, uno lo lee y va cambiando puntos y comas, luego lo lee de nuevo y los vuelve a poner como estaban. En mi caso, la última corrección es una lectura al grabador, que luego escucho con los ojos cerrados. Aplico un principio muy simple: si funciona en la escritura no necesariamente funcionará en la lectura en voz alta, pero si funciona en lo oral funcionará también en la lectura silenciosa.

No tengo idea sobre cuantas versiones lleva un texto, porque no hay límites precisos entre una y otra (nunca reescribí uno íntegramente desde cero, sino que voy gradualmente transformando la primera versión.). Cuando está terminado, todos los papeles van a un bibliorato, y éste a lo alto de un ropero. Conservo aparte las notas preparatorias (fechas, biografías de personajes, etc.) porque mis novelas se continúan unas en otras y debo cuidar la coherencia informativa.

4. ¿Considera que uno puede decidir « entrar en literatura » o que es algo que simplemente acontece ? ¿Cuándo se sintió escritor por primera vez ? ¿Cuál considera que es su primera obra?

En mi caso, fue una decisión : en mis primeros intentos por "entrar en a literatura" me quedaba en la puerta como el campesino de Kafka. Otras veces me dejaron pasar pero era una habitación equivocada, un sucedáneo de pesadilla, una variante degradada a lo Philip K. Dick. Así escribí una novela espantosa cuyos últimos ejemplares, por suerte, descubrí y destruí hace poco: no fuera que a mi muerte alguien los encontrara y quisiera publicarlos. Seguí empeñado en entrar, y cuando escribí mi cuento "Marina en sol y azul cobalto" finalmente me encontré adentro de, no sé si la literatura, pero sí de $m i$ literatura. Eso era lo que yo podía hacer. Ni más, ni menos. 
5. ¿Le parece que se puede « aprender a escribir » ?Qué diría en su caso ?

Aprender, sin duda. Uno aprende solo, leyendo (tanto a los buenos como a los malos) y luego avanza a tientas, por ensayo y error. En mi caso, nunca aprendí a escribir bien, pero sí a tener registro corporal (se lee con el cuerpo, sin duda) de lo que está mal escrito. La decisión, entonces, es no dejarlo pasar, y volver a intentarlo. Y si nunca se llega, eliminarlo.

Enseñar, quién sabe. Nunca fui a talleres literarios, ni los dicté. Lo que observé en mi paso por lugares como el IWP de Iowa es que la enseñanza institucional (como es el caso en Europa y Norteamérica) o artesanal (como el nuestro) lo que logra es subir el piso, más que el techo. Lo que de todos modos marca una importante diferencia, sobre todo en la escritura de crónicas, investigaciones periodísticas, artículos, ensayos, etc. : hay un nivel básico de calidad que muchas veces entre nosotros, por falta de este aprendizaje formal, no se alcanza. Los talleres y carreras de escritura garantizan eso, al menos. Ahora, pegar el salto a la institución de un "Ph. D. in Creative Writing” es, creo, algo desmesurado.

6. ¿Cómo reacciona al escuchar hablar de «mala escritura »? ¿Le parece que hay un ideal de estilo ? ¿Qué opina de los ejercicios « de taller » 0 « de estilo »?

Gracias a Roberto Arlt, hemos tomado conciencia de que hay muchas formas de escribir bien, y que no hay un ideal de estilo. Gracias a los traductores españoles, hemos aprendido a desconfiar de lo que Borges llamaba "las vanas simetrías del estilo español" y Semprún "el viscoso acervo de la castellana retórica", y también del Diccionario de la RAE, que no tiene nada para decir en lo que a nuestro español respecta.

\section{Daniel Guebel}

1. ¿Podría contar, de la manera más detallada posible, cómo y dónde escribe ? ¿Sigue escribiendo a mano ? ¿Hay algún instrumento o soporte que privilegia?

Escribo en computadora, en mi casa, pero a veces tomo notas en cuadernos o libretas. Cuando escribo a mano tengo la impresión de trabajar sobre puntos, condensaciones, los núcleos de la escritura.

2. A la hora de escribir, ¿empieza por el principio ? ¿Cómo se prepara para la escritura (lecturas, ritos, cábalas...)?

No hay preparación, sino acceso y vacilación inicial. Ningún rito. Escribir reordena la biblioteca, arma nuevas secciones, guía búsquedas. En un par de libros he trabajado con libros a mano, apuntes, información de internet.

3. ¿Cuándo considera que el texto está terminado? ¿Cuántas versiones escribe, en promedio, antes de publicar? ¿Conserva todo lo que escribe? ¿Qué hace con ellos? ¿Los relee alguna vez ? ¿Tiene un archivo personal ?

No escribo versiones. La terminación no tiene nada que ver con el "acabado", en el sentido del pulimiento y la perfección formal, la eliminación de rimas y repeticiones, sino con un trabajo deliberado de eliminación de las vanidades y exhibicionismos del narrador. Es una tarea de supresión moral, o de eliminación criminal de la fuente del goce obsceno, hasta dejar un hablante soportable. Releo lo que escribo cuando quiero pensar que hice algo. ¿Archivo ? Sí, cajas, con las fuentes de mis libros, para que me lo compre alguna universidad, alguna vez. 
4. ¿Considera que uno puede decidir « entrar en literatura » o que es algo que simplemente acontece ? ¿Cuándo se sintió escritor por primera vez? ¿Cuál considera que es su primera obra?

No recuerdo haberme sentido otra cosa que escritor, desde antes de haber escrito una sola palabra. No sé cuál es mi primera obra, libros que perdí. Lo primero que publiqué me parece ajeno, pero eso es estimulante, porque prefiero a los autores cuya obra se desconoce entre sí. En mi caso, puedo intentar el ingreso a la literatura, pero me resulta mucho más fácil si ya estoy escribiendo: derivar un libro de otro, repentinamente. Comenzar, en cambio, a veces es difícil. Hay una especie de principio de selección innato, una resistencia inicial, que evalúa la intensidad de presión del deseo de escribir, y que impide el paso a la escritura si esa presión no es suficiente. Me gustaría apoderarme de esa llave o válvula.

5. ¿Le parece que se puede « aprender a escribir »? ¿Qué diría en su caso ?

Claro. Para eso está la escuela.

6. ¿Cómo reacciona al escuchar hablar de «mala escritura»? ¿Le parece que hay un ideal de estilo ? ¿Qué opina de los ejercicios « de taller » 0 « de estilo»?

"Mala escritura" era la expresión que tradicionalmente usaban los escritores para referirse a la obra de sus colegas y reservarse el valor de la diferencia. Astutamente, César Aira se la apropió para, me imagino, definir su propia escritura como el signo de lo nuevo respecto de la producción dominante hasta el momento de su aparición. Esta política del valor es propia de todo autor apreciable.

\section{Martín Kohan}

1. ¿Podría contar, de la manera más detallada posible, cómo y dónde escribe? ¿Sigue escribiendo a mano ? ¿Hay algún instrumento o soporte que privilegia?

Escribo a mano, con lapicera a tinta, en cuadernos de hojas rayadas. Uso distintas lapiceras, pero mantengo siempre la misma a lo largo de todo un libro. Museo de la Revolución con una Mont Blanc, Ciencias morales con una Inoxcrom, Cuentas pendientes con una Parker, Bahía Blanca (la que acabo de terminar) con una Lamy. Prefiero las plumas de trazo grueso. Me gustan el olor del papel, el olor de la tinta, el rasgado del trazo, el dibujo de la letra; lo disfruto. Hay también, o principalmente, una razón literaria, y es que el ritmo de la escritura a mano entra en perfecta correspondencia con el ritmo del fraseo en mi cabeza, se acompasan exactamente. En cambio el tipeo en teclado, que me desagrada como ejercicio, presenta además el problema de una excesiva velocidad en los dedos, que hace que el ritmo del fraseo y el ritmo material de la escritura se desencuentren. Utilizo cuadernos Rivadavia, los clásicos cuadernos escolares de Argentina. Tienen formato mediano, hojas gruesas, buena calidad de papel. Prefiero los de cien páginas. Intenté una vez con uno de doscientas, pero el brazo queda colgando en el aire. Si bien al pasar los textos a máquina corrijo algunas cosas, la versión inicial escrita a mano se mantiene bastante en la versión definitiva. No es para mí una escritura provisoria, sujeta a confirmación. Es para mí la escritura de la novela.

En cuanto a los lugares, escribo exclusivamente en los cafés. Necesito ese entorno, el contacto con la calle, con la ciudad, la compañía de otra gente (que acompaña a razonable distancia y con óptima ajenidad). No escribo jamás en mi casa, que es un sitio donde no me gusta estar y por lo tanto donde no me gusta escribir. Voy pasando de bar 
en bar a lo largo del día. Elijo uno u otro según mi estado de ánimo o mi disposición de escritura : a veces alguno más tranquilo, o esos bares un poco retirados que hay dentro de algunas librerías ; otras veces preciso el movimiento y el ruido de fondo.

2. A la hora de escribir, ¿empieza por el principio? ¿Cómo se prepara para la escritura (lecturas, ritos, cábalas...) ?

Empiezo por el principio, no salteo, no dejo para después, no paso a la oración siguiente si no considero resuelta la oración en la que estoy. Soy armadito y estructurado y escribo de esa misma forma. En cuanto a preparación, me basta con la puesta en escena de la mesa de café.

3. ¿Cuándo considera que el texto está terminado? ¿Cuántas versiones escribe, en promedio, antes de publicar? ¿Conserva todo lo que escribe? ¿Qué hace con ellos? ¿Los relee alguna vez? ¿Tiene un archivo personal ?

Escribo una sola versión. Si sale mal, doy la novela por perdida y me pongo a escribir otra; pero no sumo versiones. No puedo hacerlo, pierdo interés. Vuelvo sobre esa versión para hacer ajustes y correcciones, que tampoco son tantos; pero nunca al punto de reescribir. Los pasos son : la escritura del texto, con vueltas atrás de relectura para entrar en tono; estacionar el texto un tiempo (unas semanas); volver a leerlo en el manuscrito para evaluar si vale la pena el trabajo de pasarlo; en caso de que valga la pena, tipearlo a máquina, lo que es una reescritura, pero reescritura de lo mismo ; luego un par de lecturas más, en el impreso. Si en esas dos lecturas me conforma, lo doy por terminado para mí, y lo paso a los tres o cuatro amigos de confianza que lo leen y me dan sus opiniones. Algunos ajustes más surgen a partir de esas consideraciones. Luego el texto va a la editorial. Cuando recibo las pruebas de imprenta, leo todo otra vez con cuidado, porque el texto ya asume la forma de libro y me entra el miedo. De todas formas, entre lo que queda escrito a mano en los cuadernos y lo que aparece impreso en los libros noto que las diferencias son más bien pocas.

No conservo nada de lo que escribo. Apenas el libro sale, le regalo el cuaderno a alguien ; amigos, pareja. Si se trata de un acto de generosidad, puede que sea el único de que dispongo. No me releo salvo casos de fuerza mayor (lecturas públicas, por ejemplo). No tengo ningún archivo personal.

4. ¿Considera que uno puede decidir « entrar en literatura » o que es algo que simplemente acontece ? ¿Cuándo se sintió escritor por primera vez ? ¿Cuál considera que es su primera obra?

Yo me siento atraído por la escritura, antes que por la condición de escritor. Por lo tanto lo que me importa es entrar "en escritura", en "entrar en literatura" no pienso demasiado. $Y$ entrar en escritura me resulta algo tan pleno y tan fluido como un deseo que se realiza. Empecé a sentirme escritor cuando alguien me dijo que parecía un falso modesto, o más decididamente un tonto, diciendo que no me sentía escritor. Considero a La pérdida de Laura mi primera obra, porque es lo primero que se publicó. Quizás elegiría otro, alguno de los anteriores, si en vez de "obra" pensara en "texto", tal como decía Barthes.

5. ¿Le parece que se puede " aprender a escribir »? ¿Qué diría en su caso ?

Me parece que aprender a escribir es una variante dentro de otra destreza, que es la de aprender a leer. Creo que es cierta manera de aprender a leer; o mejor dicho, que es aprender a leer de cierta manera. 
6. ¿Cómo reacciona al escuchar hablar de «mala escritura »? ¿Le parece que hay un ideal de estilo ? ¿Qué opina de los ejercicios « de taller » 0 « de estilo »?

Distingo por lo menos dos usos diferentes de la noción de "mala escritura". Una sería la de Roberto Arlt, por ejemplo, una impugnación crítica de una noción estandarizada y convencional de lo "bien escrito", pensado además como paradigma de clase. Pero me temo que hay otro uso, que sería la mera coartada de quienes escriben mal sin atentar contra ninguna convención, ninguna estandarización, ningún paradigma de clase : simplemente escriben mal. A mí me parece legítimo cuestionar esa mala escritura, la de quienes no parecen tener ninguna relación singular con el lenguaje y con sus formas, o que en cierto modo parece no importarles.

Considero que la "escritura correcta", la del ejercicio de taller por ejemplo, es igualmente antagónica de lo que entiendo por buena escritura. La buena escritura (que puede ser la "mala escritura" de un Arlt) se opone tanto a la escritura correcta de la pura convención como a la mala escritura de los que no cuestionan nada y simplemente escriben mal, y que a menudo curiosamente son los mismos que practican la escritura "correcta".

\section{Damián Tabarovsky}

1. ¿Podría contar, de la manera más detallada posible, cómo y dónde escribe ? ¿Sigue escribiendo a mano ? ¿Hay algún instrumento o soporte que privilegia?

Escribo en una PC, desde hace muchos años. Antes lo hacía en una máquina de escribir. No escribo a mano desde que terminé la escuela secundaria. Creo que es lo único bueno que me enseñó el periodismo.

Escribo en mi escritorio, que además es el garaje de mi casa. Me gusta la idea de "literatura de garaje", un poco como el rock de garaje : esa música cruda, directa e irresistible de viejas bandas norteamericanas de clase B. Le hicimos una limpieza de cara (pintamos las paredes, pusimos veladores) pero el piso tiene todavía una mancha irreductible (no se si de aceite o grasa) y no pudimos sacar las canillas y una rejilla en el suelo. No sé por qué, pero algo de eso me gusta. Entre tanto, frente a mi biblioteca está la bicicleta de mi hija, una valija que volvió rota de un viaje y quedó allí, una pelota de mi hijo, y una lámpara que nunca pusimos en su lugar.

Escribo de noche.

2. A la hora de escribir, ¿empieza por el principio ? ¿Cómo se prepara para la escritura (lecturas, ritos, cábalas...)?

¿La escritura de una novela ? Supongo que sí, ¿a quién podría interesarle cómo escribo mis artículos del diario ? (pero más aún, ¿a quién podría interesarle cómo escribo una novela? O, rozando la generalidad, ¿por qué debería interesarnos cómo un escritor escribe ?). Necesito tener dos cosas: el título, y la primera frase. Hasta que eso no aparece, no hay comienzo. Y luego escribo muy rápido, o mejor, dicho, muy lento. Es decir : escribo rápido (una página en una hora), pero pueden pasar días o semanas sin escribir. Entonces tardo un año en escribir, digamos, 50 páginas. Hasta que comienzo a aburrirme de la novela (ya se me ocurrió otra) y me encierro y escribo las 50 restantes de un tirón. No es un método, es apenas una constatación fáctica. 
3. ¿Cuándo considera que el texto está terminado? ¿Cuántas versiones escribe, en promedio, antes de publicar? ¿Conserva todo lo que escribe? ¿Qué hace con ellos ? ¿Los relee alguna vez ? ¿Tiene un archivo personal ?

No escribo demasiadas versiones, trabajo en general sobre "el original" (pocos términos mas complejos de pensar, en términos estéticos/culturales y tecnológicos, que la noción de "original"). Corrijo poco, cambio algunas cositas, no mucho más.

Una vez que el texto sale de imprenta está terminado. Quiero decir : varios de mis libros han sido traducidos y algunos viejos, reeditados en nuevas ediciones, y nunca cambié “el original". Es como una especie de testimonio de cómo escribía yo en ese entonces.

4. ¿Considera que uno puede decidir « entrar en literatura » o que es algo que simplemente acontece? ¿Cuándo se sintió escritor por primera vez? ¿Cuál considera que es su primera obra?

Mi primera obra es Fotos movidas, mi primera novela publicada (Grupo Editor Latinoamericano, Buenos Aires, 1992).

Más allá de ese detalle, la pregunta por el "entrar en literatura" (quizás la pregunta fundante de la sociología de la literatura, que no es más que la pregunta por la legitimidad de la literatura) me sigue pareciendo clave y no deja de interpelarme, aún hoy (¿pero qué significa "aún hoy” ? ¿Ahora que ya escribí cierta cantidad de libros? ¿Ahora que algunos de ellos han encontrado cierto eco? Difícil saberlo). Entre otras cosas, Literatura de izquierda no deja de merodear en torno a esas cuestiones.

Pero sí es cierto que, un día, me dije : "escribo" (aunque no diría que "soy" escritor : tengo una marcada aversión por el verbo ser, por las identidades fijas, por los lugares a salvo de conflictos. ¿Alguien puede publicar un libro que se llame Ser escritor sin caer en el ridículo ?). ¿En qué momento dije entonces “escribo" ? Quizás a partir de un pasaje de mi novela Bingo, que todavía encuentro logrado. 0 , tal vez, por cierta resignación : el contexto (el campo : otros escritores, editores, periodistas, libreros, etc.) me connota como "escritor", y aquí estoy....contestando esta encuesta.

5. ¿Le parece que se puede « aprender a escribir »? ¿Qué diría en su caso ?

La enseñanza está, para mí, directamente ligada al olvido. Si escribo mejor ahora que antes, si aprendí algo, es precisamente porque olvidé algunas de las preguntas que me hacía antes de mi primer libro. Pues : no creo que se aprenda a escribir. En mi caso, tan sólo avanzo saltando de olvido en olvido.

6. ¿Cómo reacciona al escuchar hablar de «mala escritura»? ¿Le parece que hay un ideal de estilo ? ¿Qué opina de los ejercicios « de taller » 0 « de estilo»?

Los únicos talleres que respeto son los de corte y confección.

\section{Diego Vecchio}

A decir verdad, resulta muy difícil contar cómo se escribe. Ignoro cuáles son mis rituales y cábalas (si es que practico algún tipo de ritual o de cábala a la hora de escribir). No sabría explicar los preparativos y los preliminares (si antes de comenzar, elaboro un plan detallado o si prefiero evitar, en lo posible, toda programación), mucho menos describir ciertas prácticas materiales (escribo por la mañana o por la noche, escuchando música o en un silencio sepulcral, aprovechando las ventajas de las nuevas tecnologías o a mano, con una lapicera fuente marca Parker o un marcador Pilot de trazo fino, en un cuaderno Claire fontaine o en un cuaderno Laprida forrado con papel araña). Los procesos de escritura se me imponen, como un tic en el párpado y, como un tic en el 
párpado, escapan a cualquier tipo de explicación. El ojo que ve no puede verse a sí mismo, al menos que se contemple ante un espejo, pero que le devolverá un reflejo invertido. Lo más cotidiano en realidad es lo que me resulta más extraño. Los preparativos, preliminares, rituales, cábalas, forman parte de una suerte de inconsciente, que no se deja aprehender, a no ser indirectamente, a través de un simulacro, o, como le gustaba decir a Felisberto Hernández, una explicación falsa. Soy un escritor de la familia ursina (al menos en uno de mis libros).

Para empezar hace falta, como diría Godart, no tanto encontrar la palabra justa, sino justo una palabra y esta palabra fue precisamente OSO.

Lo que me llamó la atención fueron sus características gráficas. OSO presenta una particularidad en nuestra lengua, por no decir, por temor a exagerar, en todas las lenguas. No solo puede leerse de izquierda a derecha o de derecha a izquierda, como los palíndromos, sino que puede rotarse unos $180^{\circ}$, sin la más mínima alteración.

10

\section{os o \\ $\leftarrow$ \\ $\curvearrowleft$ \\ os O}

$\uparrow$

Esta palabra acróbata, que puede darse vuelta en todos los sentidos, sin dejar de ser la misma, designa en primer lugar a un mamífero carnívoro plantígrado, de pelaje pardo, corpulento, cabeza grande, ojos pequeños, extremidades con garras y cola muy corta.

11 Noventa grados de rotación y tenemos una serie de variantes: oso panda, oso hormiguero, oso polar, oso andino, oso marino, oso marsupial.

Diez grados más y encontramos expresiones figuradas, tales como "hacerse el oso" (hacerse el tonto) o "hacer alguien el oso" (exponerse a la burla o lástima de la gente, haciendo o diciendo tonterías o bien galantear, cortejar sin reparo ni disimulo).

Cuarenta grados y tenemos a una sub-cultura gay, formada por hombres rollizos y velludos, en oposición directa con el estereotipo de belleza masculina, encarnado por los efebos imberbes que el barón Wilhelm von Gloeden fotografió en Taormina.

Michel Pastoureau consagró un estudio minucioso a la historia del oso, que en tiempos prehistóricos, parece ser, fue adorado, en grutas y cavernas, como un dios. Vestigios de esta religión se infiltraron en los mitos griegos y en ciertos rituales de los pueblos germanos, que veneraron en el más grande y poderoso de todos los mamíferos europeos, no solo al rey de los animales, sino también a un intermediario entre el mundo de los hombres y el de los dioses. Todo cambió con el cristianismo. Desde la costa africana, donde no había osos, San Agustín sentenció ursus est diabolus ("el oso es el diablo"). No fue de extrañar que el Maligno se presentara ante algunos monjes penitentes, para alejarlos de la buena senda, adoptando la forma de un oso. En su voluntad de erradicar todo resto de idolatría, la Iglesia le declaró abiertamente la guerra al oso, organizando una verdadera persecución, por no decir exterminación de este animal, no solo en los bosques sino también en el espacio simbólico. El oso fue destituido como rey de los animales y en su lugar se erigió a un monarca oriental: el león. En el bestiario medieval, el oso es representado como un animal tonto, torpe, lujurioso, irascible, felón, gordinflón, ladrón de miel. Convenientemente encadenado y con el hocico aprisionado en un bozal, fue exhibido en ferias y en circos por artistas trashumantes. El oso terminó vengándose de 
tantas calumnias y humillaciones en el siglo XX, al reencarnarse en el juguete más popular de todos los tiempos : el oso de peluche. Transformados en pequeños salvajes, los niños le rindieron culto a este tótem, volviendo a practicar, sin saberlo, una religión primitiva, que no escapó a los psicoanalistas. Inspirándose en su Majestad el Oso de Peluche, Donald Winnicot elaboró su teoría del objeto transicional, fundador de un espacio situado paradójicamente entre el adentro y el afuera, predecesor del famoso objeto a lacaniano, que los traductores al español tendrían que haber designado, para hacer justicia al oso, objeto 0.

Algo que todavía sigue siendo un misterio : ¿de qué manera, un animal tan temible como un oso, pudo haberse convertido en confidente y protector del sueño de los niños?

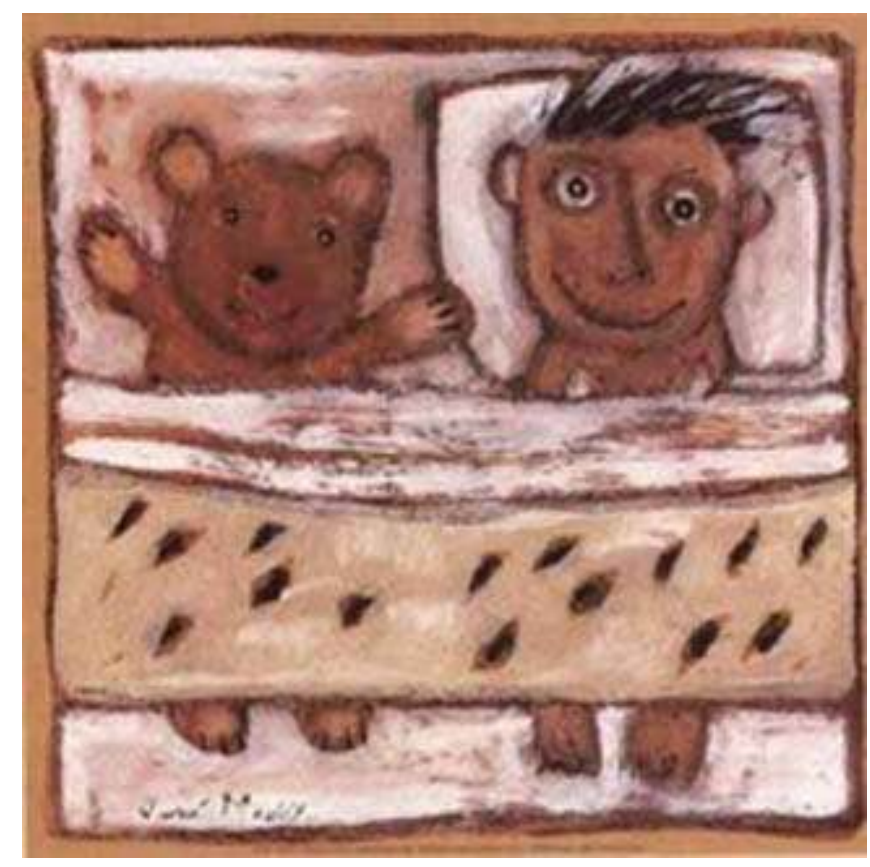

Las palabras no están solas. Una palabra nos lleva a otras palabras. Y estas otras palabras, a otras. Y luego a otras, hasta el agotamiento. El lenguaje no está solo, replegado sobre sí mismo, como un erizo. El lenguaje está abierto y desplegado, como una trampa para ratones, dispuesto a capturar a quien por inadvertencia acerque su hocico. La literatura no es autónoma (ni mucho menos post-autónoma) sino omnívora.

Las palabras llevan no solo a otras palabras sino también a estados de cosas, materiales e inmateriales. Las ficciones trafican con la vida y la vida termina acomodándose a la ficción, a tal punto de que ya no se sabe que es lo que copia a qué. Resulta inútil determinar un orden, atribuir un rango, definir una sentido. Se producen sincronías que borronean los contornos y jerarquías.

Ni bien se me ocurrió la idea de escribir algo sobre osos, comencé a tropezarme con osos en la vida. O tal vez haya que afirmar lo contrario : los osos ya estaban en mi vida, bajo formas diversas, por eso me llamó la atención esta palabra.

Todo comenzó con una conversación.

Una amiga me cuenta un método que había inventado para hacer dormir niños que no podían -o no querían - dormir y que consistía en ofrecerle al niño insomne un oso de peluche también insomne, pidiéndole que lo ayudara a conciliar el sueño. El método, parece ser, resultaba eficaz. Como el oso resultaba ser mucho más tenaz en el insomnio que el niño, el niño terminaba durmiéndose, harto de aplicar los mismos métodos que los adultos aplicaron sobre él. 
Comienzo a escribir el libro, no recuerdo si antes o después de esta charla. Lo que sí recuerdo es que, mientras escribía OSOS, llegaron, me fueron llegando, no dejaron de llegar, encomiendas, enviadas desde las montañas por esta misma amiga, quien, además de ser una reconocida experta en insomnio infantil es también coleccionista de osos de peluches, con ejemplares pardos, cobrizos, dorados, blancos, negros, amarillos, azules, rojos, anaranjados, de pelo suave o áspero, con patas rígidas o articuladas, con sombrero o sin sombrero, vestido con impermeable o púdicamente desnudos.

Para no ser menos, mis otros amigos también comienzan a regalarme osos de peluche, de todas formas y colores, para mi cumpleaños, para navidad, para el 21 de octubre (día de Santa Úrsula, santa que lleva en su nombre la palabra ursus), el 11 de noviembre (día de San Martín, que coincide con el comienzo de la hibernación del oso), el 14 de febrero (día de San Valentín y que coincide con el final del letargo invernal), o simplemente para festejar alguna querella seguida de una reconciliación, algún encuentro ursino fortuito.

Fui acomodando estos dones primero en mi cama y cuando la cama resultó demasiado estrecha, en dos estanterías que instalé en mi dormitorio y cuando ya no hubo más lugar, apilé cuidadosamente a los osos que me iban regalando en un rincón del dormitorio, formando una montaña ursina, que no dejó de crecer y desmoronarse.

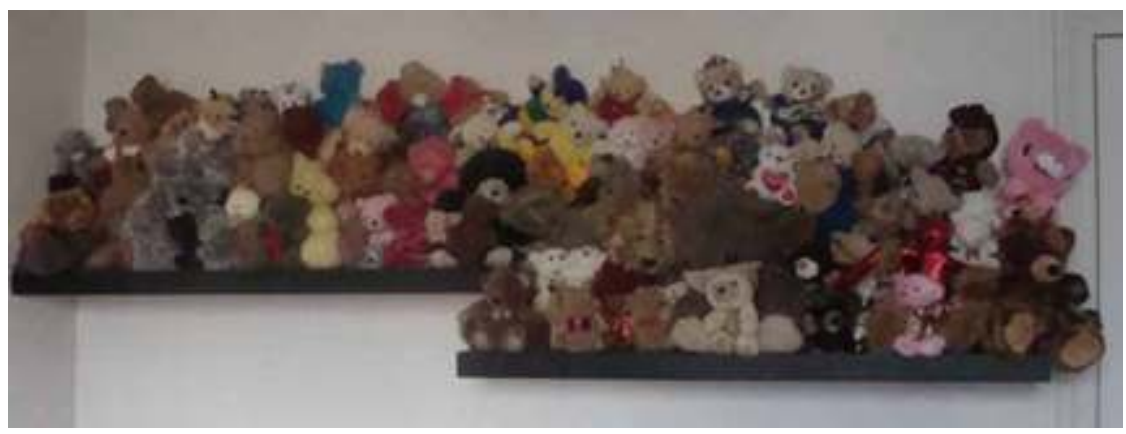

- Es mucho peor que una juguetería- dijo un visitante, al entrar en mi cuarto y descubrir, de manera imprevista, la instalación.

- Con tan solo mirarlos, me da un ataque de asma-dijo otro.

- Te están infantilizando.

Pero ya no es posible dar marcha atrás y escapar a este devenir-niño. Los osos venían a mi encuentro o yo iba al encuentro de los osos.

Abrí un blog, que intentaba ser una especie de diario y borrador ursino, donde fui registrando la llegada de los nuevos osos a la colección y archivando los diferentes materiales utilizados durante la escritura del libro: libros, videos, fotografías, historietas, las instalaciones traumáticas de Mike Kelly, las máquinas crueles de Annette Messager, The Teddy Bear's Picnic.

Al salir de mi casa, un día encontré, al lado del tacho de basura, abandonada, una inmensa cabeza de oso, desprendida de su cuerpo, a la manera de una escultura olmeca, llamándome, pidiéndome que la incorporara a la colección. Y eso hice.

Una vecina finlandesa siguió encontrando, también abandonados, en el tacho de basura de nuestro edificio, algunos osos de peluche, que recogió, lavó y reparó piadosamente, reconstruyendo un brazo que había sido amputado, cosiendo un ojo de plástico que se había desprendido, rellenando con gomapluma un vientre flácido que había perdido su interior por un costado, antes de enviarlos a un orfelinato de osos de peluche, situado en Helsinki.

Leí en un diario que, en ciertos hospitales franceses, el servicio de pediatría trabaja en 
activa colaboración con los osos de peluche para calmar las angustias de los pacientes. Cuando un niño ha de ser sometido a una operación quirúrgica, el cirujano le presenta a un oso de peluche, que también ha de ser sometido a la misma operación quirúrgica, explicándole, con un bisturí juguete, los detalles de la intervención.

Descubrí y quedé fascinado con un documental de Agnès Varda, Ydessa et les ours, etc, sobre Ydessa Hendeles, una coleccionista de arte contemporáneo, nacida en Canadá, hija de una pareja de sobrevivientes del Holocausto, quien organizó una muestra en Munich, repartida en dos salas : la primera, con los muros saturados de los zócalos hasta el techo con más de dos mil fotografías de osos de peluche y la segunda, totalmente vacía, con una escultura de Maurizio Cattelan, que representa a Hitler, rezando de rodillas.

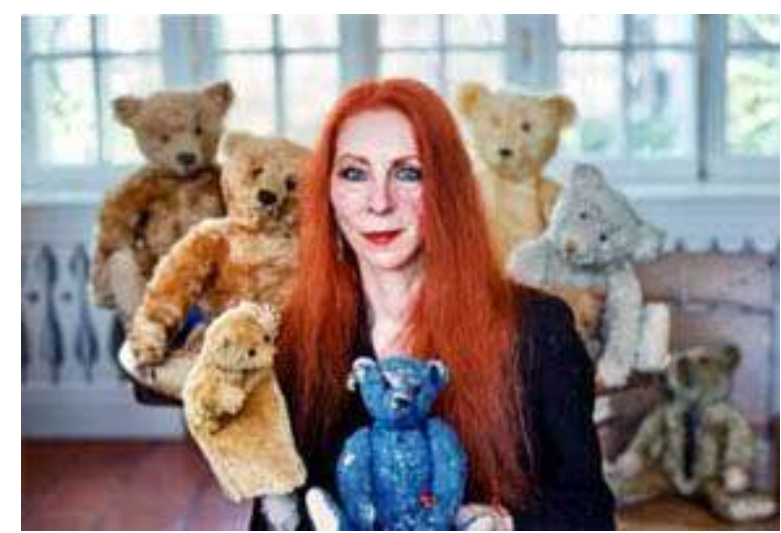

Descubrí y quedé no menos embelesado por otro documental, Grizzly man, esta vez de Werner Herzog, que reconstruye la vida de Tim Treadwell, un ecologista californiano que se fue a vivir con los osos de Alaska, para filmar con una cámara de video algunos momentos de esta vida ursina, que incluyó su propia muerte, devorado por un oso. Lo que no es de extrañar. Basta cambiar algunas letras para transformar OSO en OGRO. Pienso en el célebre Gloomy Bear, oso de peluche color rosado, con las garras, el pecho y el hocico ensangrentados, que alguien me regaló y cuyo nombre ya no recuerdo, creado por el diseñador japonés Mori Chuck, adoptado por Pitty, un niño desprevenido, que terminó salvajemente asesinado por Gloomy Bear. En ciertas ocasiones, los osos de peluche pueden resultar criaturas bastante siniestras.

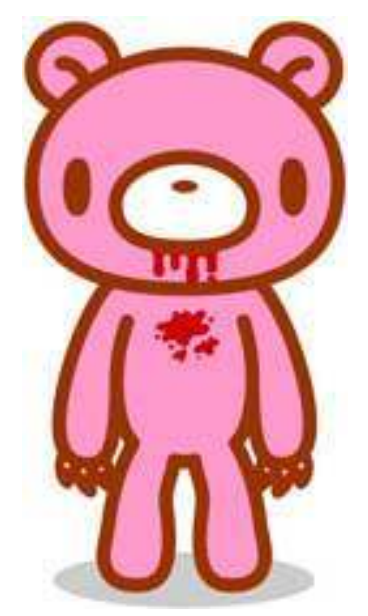

Como las monomanías y las religiones monoteístas - aún en su versión totémica- no conducen a nada bueno, fue necesario, para compensar, encontrar otro animal. Esto fue 
lo que me ocurrió leyendo a Jean Pierre Brisset, un empleado de la estación de trenes de Angers, autor de una serie de tratados de gramática y de profecías, quien, el 5 de enero de 1883 tuvo una revelación, donde descubrió la ley fundamental del calembour o el principio de equivalencia fonética, que más tarde explorarán, no sin fortuna, Raymond Roussel y Jacques Lacan.

Aprovechando este procedimiento homofónico, Brisset sienta las bases de una nueva ciencia del lenguaje imaginaria, adelantándose a todas las tentativas de cierta paleolingüística que aun se obstinaba en reconstruir el árbol genealógico de las lenguas indoeuropeas, a partir de una improbable lengua primitiva.

Sin preocuparse de las pruebas, ni mucho menos de la evidencia histórica, Brisset sostiene que el latín no es una lengua natural, como se creyó equivocadamente durante dos milenios, sino una lengua artificial, al igual que el esperanto, un infame simulacro con que se torturó a los escolares y se oprimió a los pueblos. Según Brisset, lingua latina quiere decir lengua transpuesta. Y concluye : el latín es una especie de italiano al revés, un argot diabólico. De este modo, se saca de encima el cadáver del latín (y de las otras lenguas muertas como el griego antiguo, el sánscrito o el hebreo).

Apoyándose en un análisis pormenorizado de las posibilidades homofónicas que encierran el francés, Brisset descubre la lengua madre en la lengua que hablaban, en épocas remotas, nuestros ancestros, las Ranas. Mucho más osado que Darwin, Brisset hace descender al hombre de este simpático animalito que recibió de Dios el don de la Palabra mientras se refocilaba en un pantano a fin de apaciguar los terribles calores sexuales que lo asaltaban, profiriendo el grito sagrado : ¡Croac!

¿Acaso la RANA no es un animal perfecto -al menos por su materia vocálica- para hacerle frente a un OSO?

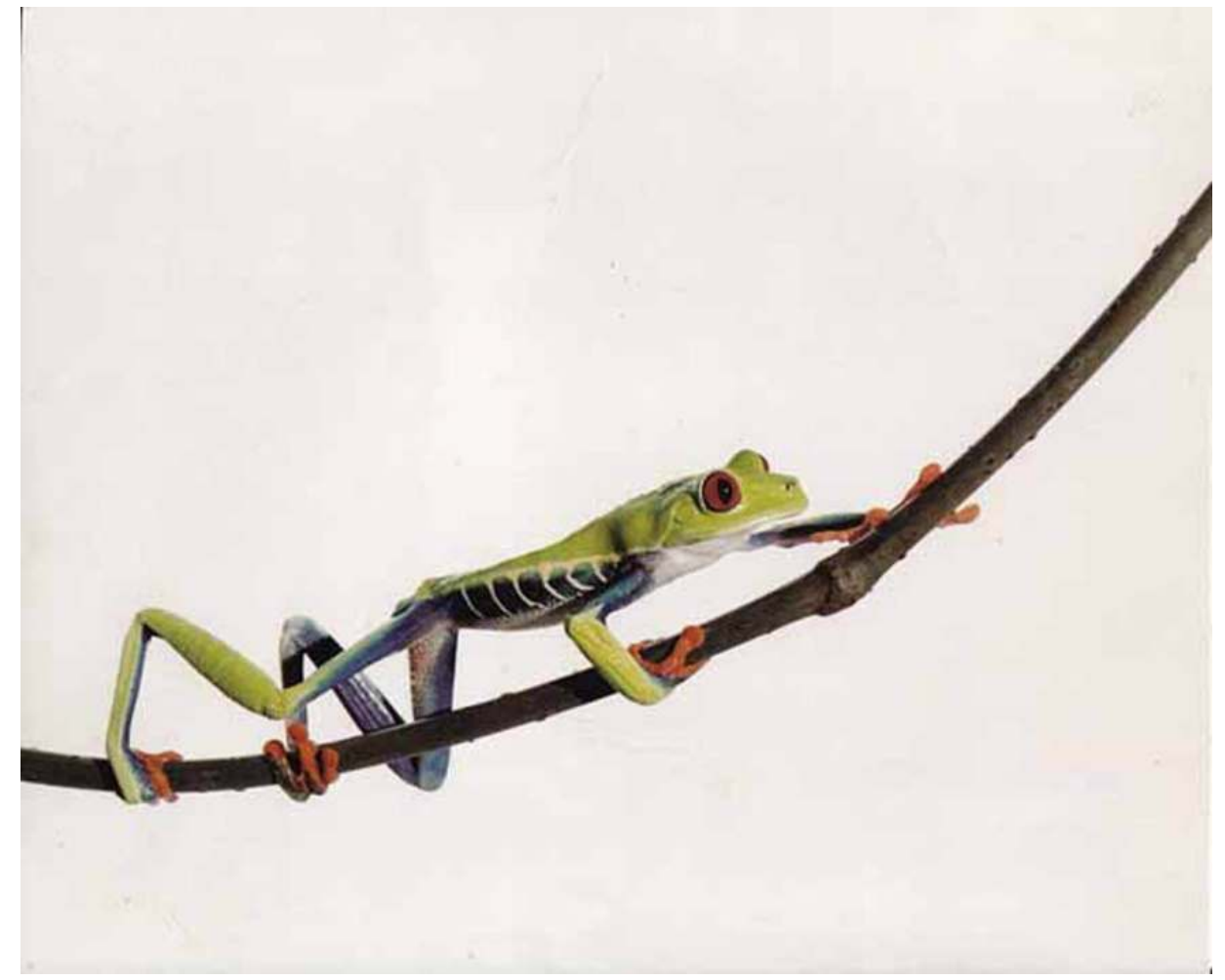

Escribí la primera versión del libro, en un mes, de un tirón, durante un viaje a Buenos Aires, en un teclado español, no sin ciertas dificultades de aclimatación dactilográfica. Acostumbrado al teclado francés, no dejaba de trastabillar todo el tiempo, presionando 
la A cuando quería escribir Q, o la Ñ en lugar de la M y en lugar de la M, una coma.

Este litigio entre los dedos y el pensamiento es uno de los tantos avatares del problema de las dos lenguas que acecha, de algún modo, en el mejor de los casos, se quiera o no, a todo escritor. Siempre se escribe entre dos lenguas, aunque solo se conozca una, puesto que una lengua es la desacomodación y la transformación de otra.

Una vez terminada la primera versión, volví a empezar una segunda y luego una tercera y hasta una cuarta, avanzando a veces, vislumbrando cuál era la dirección que había que seguir, pero otras veces tomando un camino equivocado que me obligaba a volver atrás, para suprimir algún personaje antipático o un poco chato, cambiar el lugar que rompía el flujo de la narración, volviendo a empezar, de manera mucho más parsimoniosa y errabunda, no sin titubear, bajo el influjo de Gustave Flaubert.

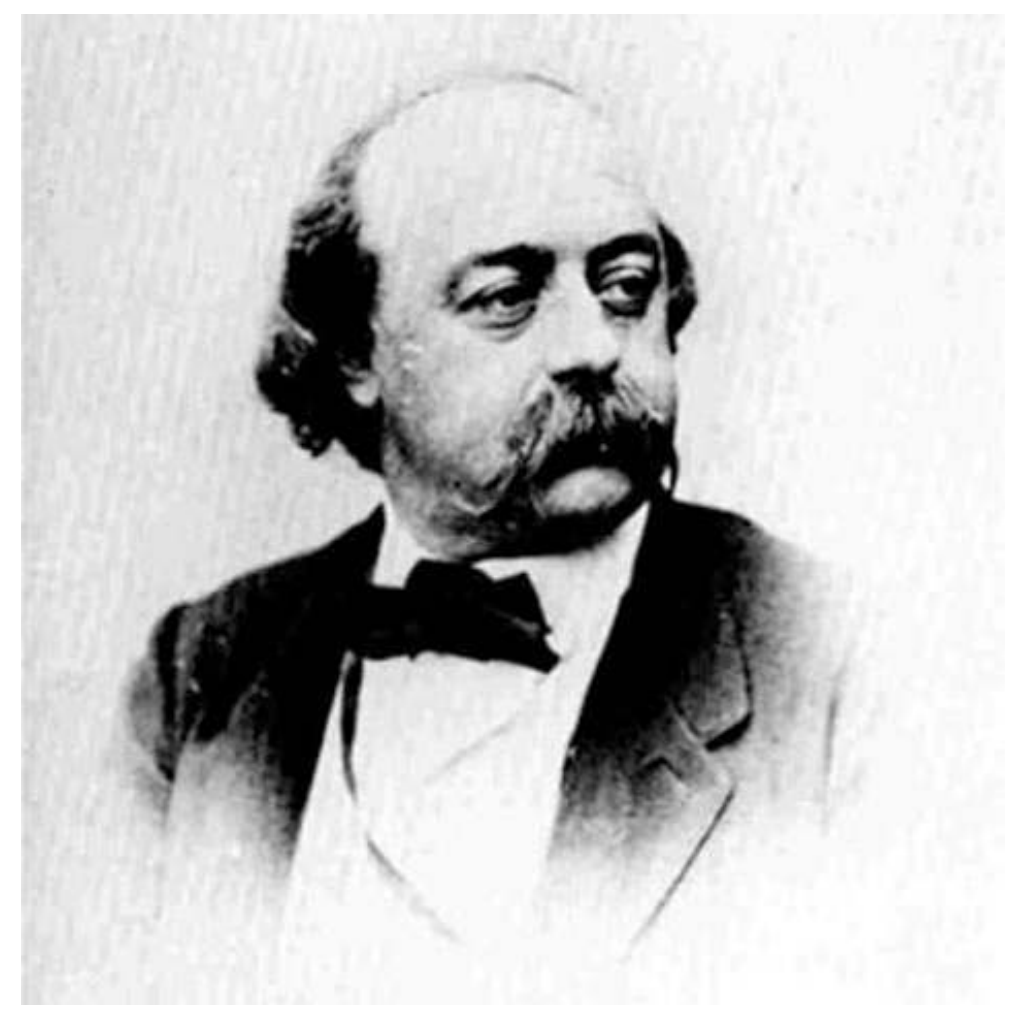

Flaubert suele ser considerado el autor de una obra preciosa y constipada (nada más que seis novelas y tres cuentos), el fundador de una nueva estirpe de escritores (la del hombre de letras como asceta de la lengua, mártir del estilo, fanático de la palabra justa), acérrimo enemigo de la inspiración y la improvisación, instigador de la literatura premeditada en sus más mínimos detalles. Este retrato es concomitante de cierta concepción de la corrección, según la cual se corrige un texto para afinar, pulir un material imperfecto, hasta darle el mayor grado de perfección posible, acercándolo al mundo de la Idea, a la manera de una fórmula matemática o una figura geométrica,.

Pero la corrección puede ser también un juego de despliegue y deriva, gobernados no por una teología de la palabra justa sino por el placer de la tachadura. Para escribir, es necesario tachar. O lo que es lo mismo : lengüetear.

Flaubert no fundó una nueva estirpe de escritor. Más bien encarnó, como ningún otro, una antigua figura : la de escritor-oso. En su correspondencia, no deja de escribir a sus amigos o a su bien amada "Soy un oso". No porque se haya encerrado en su madriguera de Croisset, a escribir a solas, gruñón y glotón, lejos del ruido del mundo, sino por tratar a sus escritos como una osa a sus oseznos.

En su Historia Natural, Plinio el Viejo escribe : "Los osos se aparean en invierno, no según la manera ordinaria de los cuadrúpedos, sino enlazados, cara a cara. Después cada uno se 
retira a su caverna. Al cabo de treinta días, la hembra da luz a unas cinco crías por lo general. Al principio son como unas masas de carne blanca, informes, un poco más grandes que un ratón, sin ojos ni pelos, solo sobresalen las uñas. Lamiendo estas masas, la osa les va dando forma y figura".

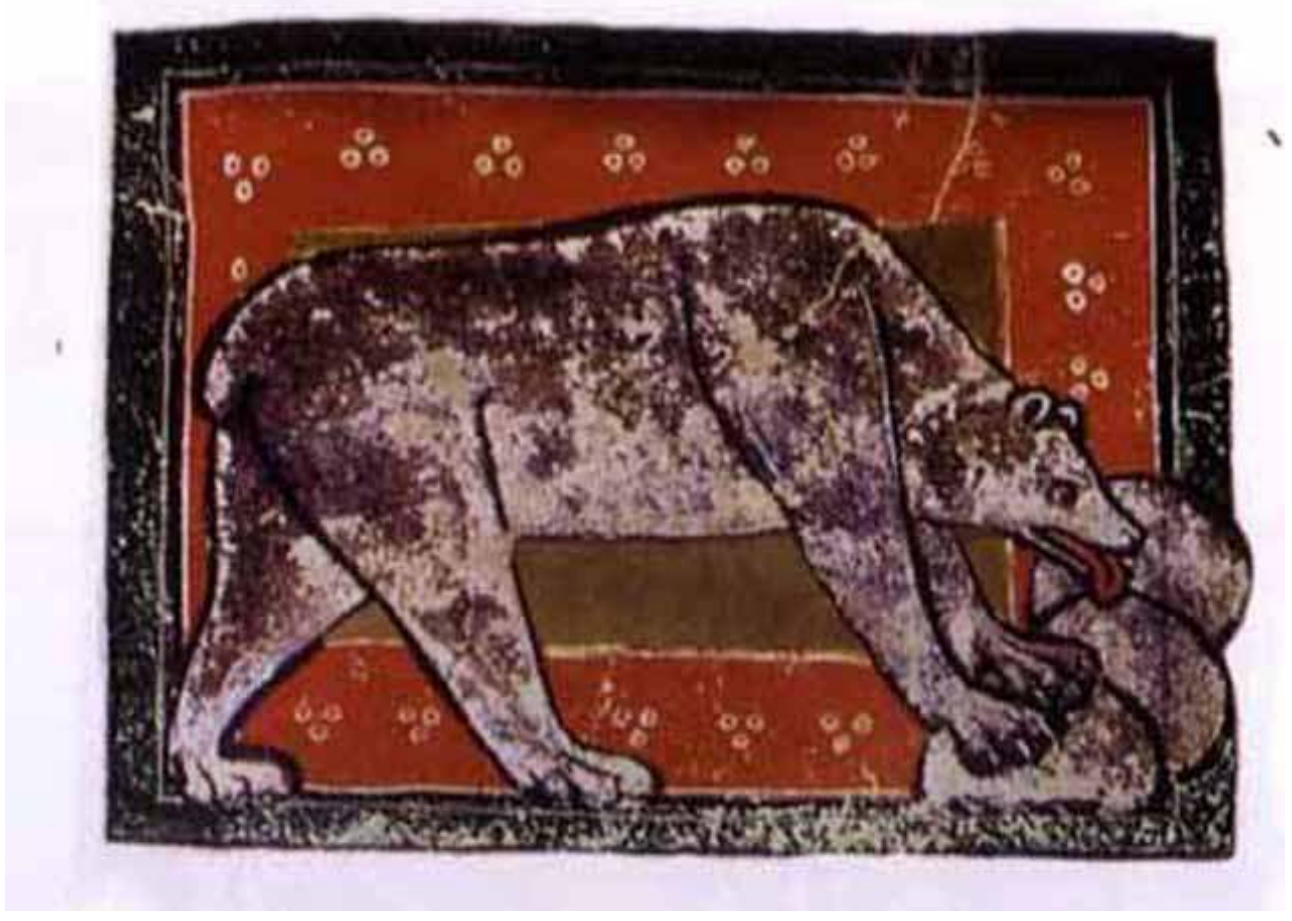

El escritor ursino es aquel que le da forma a lo informe (los balbuceos de la lengua, los esbozos de un personaje, los tropiezos de la narración). En este lengüeteo constante, nada se pierde, todo se transforma. Un fragmento desechado, es decir tachado, puede conducir a otro fragmento que nunca se me hubiera ocurrido de entrada. El principio está en el medio o en el fin. Lamiendo, sin dejar de lamer, el escritor ursino despliega una serie de figuras, que van creciendo, como mancha de tinta, sin bordes definidos, a partir de una idea que, en el mejor de los casos, se transforma y termina adoptando la forma menos pensada.

Como ciertas técnicas tántricas que intentan postergar al máximo el clímax del goce, la corrección es también una manera de aplazar el momento de concluir. El problema es que la naturaleza humana es por definición perversa y tiende a fijarse en los preliminares. La corrección puede resultar infinita, al menos que se tenga en cuenta esta recomendación de Eugène Delacroix : « La experiencia ha de enseñarnos dos cosas : la primera es que hay que corregir mucho, la segunda es que no hay que corregir demasiado ». 


\section{AUTORES}

\section{GERSENDE CAMENEN}

Université de Tours

MARIANA DI CIÓ

Université Paris III 